\title{
Wood machining with a focus on French research in the last 50 years
}

\author{
Bernard Thibaut • Louis Denaud • Robert Collet • \\ Rémy Marchal • Jacques Beauchêne • Frédéric Mothe • \\ Pierre-Jean Méausoone • Patrick Martin • \\ Pierre Larricq • Florent Eyma
}

Received: 7 October 2014 / Accepted: 13 January 2015 /Published online: 30 January 2015

(C) INRA and Springer-Verlag France 2015

\begin{abstract}
- Key message Wood machining is compulsory both for timber separation and the surfacing of wooden objects. The anisotropy, cellular nature and multi-scale level organisation of wood make its cutting complicated to study. During the last 50 years, most of the wood machining subjects were covered by French teams.

- Context Woodcutting is a very old technology but scientific research is scarce on the subject. In the last 50 years, much work on basic mechanisms as well as on industrial processes has been done in France.
\end{abstract}

\section{Handling Editor: Jean-Michel Leban \\ Contribution of the co-authors Bernard Thibaut was the coordinator of the whole paper and write part of different paragraphs, mainly 1,2,3 (with the help of Jacques Beauchêne) and 4. Louis Denaud, Robert Collet, Pierre Jean Méeausoone and Rémy Marchal contribute mainly to paragraph 4 (with the help of Frédéric Mothe) and 6. Patrick Martin and Robert Collet contribute to paragraphs 3, 4 and 6. Florent Eyma and Pierre Larricq wrote paragraph 5 and contribute to paragraph 3.}

\author{
B. Thibaut $(\bowtie)$ \\ LMGC, CNRS, Montpellier, France \\ e-mail: bthibaut@univ-montp2.fr \\ L. Denaud $\cdot$ R. Collet \\ LaBoMaP, Arts et Métiers ParisTech, Chalon-sur-Saône, France \\ L. Denaud \\ e-mail: Louis.DENAUD@ensam.eu \\ R. Collet \\ e-mail: robert.collet@ensam.eu \\ R. Marchal \\ BioWooEB, Cirad, Paris, France \\ e-mail: remy.marchal@cirad.fr \\ J. Beauchêne \\ ECOFOG, Cirad, Paris, France \\ e-mail: Jacques.beauchene@cirad.fr
}

- Aims The specific nature of wood introduces strong differences between wood and metal cutting processes. The paper focuses on French teams' contributions.

- Results The basic aspects of the tool-material interaction for different basic modes in woodcutting are highlighted. In primary conversion such as sawing, veneer cutting or green wood chipping, huge progress comes from automation and the possibility of linking the process to $\log$ and product quality through new sensors. In secondary processing, much has been done on the links between the cutting process, surface qualification and the properties of these surfaces for further processing, such as gluing or coating. Tool wear depends on the cutting process, timber quality and species. Tradeoffs are required in tool technology and coating technologies may improve tool life.

- Conclusion A large amount of knowledge and innovation has come from 50 years of worldwide research effort, with France being particularly active in this period. The transfer of skills from metals cutting industry was often a key, but much is needed to move closer to both metal cutting sector and woodcutting skills among craftsmen.

F. Mothe

LERFOB, INRA, Nancy, France

e-mail: mothe@nancy.inra.fr

P.-J. Méausoone

LERMAB, Université de Lorraine, Lorraine, France

e-mail: pierre-jean.meausoone@univ-lorraine.fr

P. Martin

LCFC, Arts et Métiers Parisech, Metz, France

e-mail: patrick.martin@ensam.eu

P. Larricq · F. Eyma

ICA, Université Paul Sabatier Toulouse III, Toulouse, France

P. Larricq

e-mail: pierre.larricq@iut-tarbes.fr

F. Eyma

e-mail: florent.eyma@iut-tarbes.fr 
Keywords Surface quality $\cdot$ Primary conversion $\cdot$ Secondary processing $\cdot$ Tool wear

\section{Introduction}

The cutting of materials has a long history in the field of crafts. The most common type is cutting material with the help of a sharp-edged tool in order to create some material removal (chips) at chosen parts of a piece of material. This paper will only examine this type of cutting, putting aside laser beam, water jet or pure splitting operations. The term machining has been used since the nineteenth century because from that period most cutting operations have been done using machines to (i) hold the tool, (ii) hold the piece and (iii) operate the guided movement between tool and piece using motorised forces. Two different objectives can be pursued in cutting operations: (i) primary conversion: getting two smaller portions from a larger piece, as in sawing operations; and (ii) secondary processing: manufacturing a predetermined shape by creating more or less complex new surfaces.

A short historical survey of woodcutting and machining history focuses on the last 50 years in the French teams' work. Results published both in peer-reviewed and grey literature (mostly $\mathrm{PhD}$ theses) by these teams will mostly be used to illustrate a kind of review of wood machining. The purpose of the article is not to make a comprehensive analysis of all the literature on wood machining but mostly to give an overview of the research made in France. Some selected publications from other different sources are cited when needed to illustrate the main aspects of wood machining.

The first chapter is dedicated to basic cutting process, beginning with an introduction to metal cutting which is a reference for all material cutting theories. Wood-specific nature is discussed with regard to the main cutting phenomena, including chip flow, cracks, cutting forces and tool wear. A second chapter concerns on primary conversion, including sawing, veneer cutting and chipping, together with the implications of growth stresses, density variations and tree branching on the machining process. The third chapter concerns on secondary processing and is mostly dedicated to the functionality of machined surfaces, looking on surface quality and surface characterisation linked to the consequences for gluing or coating. The last chapter deals with machine and tool technology.

\section{A little bit of history}

It is commonplace to divide human technological prehistory into periods related to material technology, which can be directly associated with the evolution of woodcutting.

The Wood Age was at the very beginning of the hominin species. The Stone Age is defined by the development of the ability to split flint into tools with sharp edges. It can be seen as the beginning of woodcutting, although animal jaws had been used for a long time for basic operations such as shaping a spearhead (Noël and Bocquet 1987). Oldowan hominin were using flakes of quartzite and quartz in the early Pleistocene ( 2 million years ago) to cut and scrape wood in the production or maintenance of wooden objects (Lemorini et al. 2014). Woodworking is commonly found in all archaeological layers at a site where Neanderthals lived 125,000 250,000 years ago (Hardy and Moncel 2011).

With the Bronze Age some 5000 years ago and the Iron Age some 3000 years ago, the discovery of metallurgy, and with it the possibility of forging, allowed the production of a large number of new tools with sharp edges and endless geometric forms. This led to a long golden age for woodcutting among a large number of craftsmen, whose innovations were handed down to successive generations for more than 5000 years, reaching a kind of perfection in many woodcutting operations.

The Machine Age is the last big technological revolution, arising some 400 years ago, and is associated with the beginning of material machining (mostly metal and wood to begin with). Most of the striking innovations come from machinery itself and its combination of mechanics and physics (including informatics today).

The use of machine tools was required for metal machining due to the high level of forces in most cutting operations. Research effort since 150 years was mainly put into the machining of metal (Richards 1872), and wood machining was afforded far less attention by researchers although the volume of wood chips and the quantity of woodcutting tools are far bigger than the equivalent for metal cutting. The high level of craftsmanship in many fields of woodcutting gives the impression that everything is known today about woodcutting. However, the transfer of knowledge from woodcutting to wood machining or from craft skills to scientific approaches is not obvious.

The beginning of the 1960s, when Annals of Forest Science was first published, is a key moment in wood machining, marked by the consolidation of scientific works from the post-war period in the reference book Wood Machining Process by Peter Koch (1964). The year 1963 was the year in which The International Wood Machining Seminar (IWMS) was founded, and it continues to gather wood machining scientists from around the world every 2 or 3 years. André Chardin (1920-1987), a pioneer of French wood machining research, was one of the founders of IWMS, but for the first 20 years of that 50 -year period he was almost alone with a very small team investigating cutting forces, tool wear, the cutting process and different machining processes (sawing, plaining, peeling or slicing) on many different tropical species (Boulloud 1972; Chardin 1954, 1958, 1962, 1966, 1967a, b, 1968a, b, 1971, 1973). Looking at IWMS 
proceedings (Table 1) during that period (all 10 of the earliest conferences took place in Berkeley, USA), the USA was the leader of research (with $44 \%$ of the papers) in that period, with Germany (RFA), Canada, Sweden and Norway each representing around $10 \%$ of the papers, and France and Japan accounting each for $5 \%$ (however Japanese scientists in the field had published a lot of work in Japanese and were latecomers to the IWMS conferences). In the last 30 years, which have been more precisely documented by literature databases (Table 2), Japan is the leader; France has improved its standing, being more or less at the same level as the USA now.

This improvement was the result of a strong impulse from the French government in favour of scientific research in the field of wood science. There were no $\mathrm{PhD}$ theses defended in the field of wood machining in the 1964-1983 period, but there were $37 \mathrm{PhD}$ theses in the 1984-2013 period, dealing with most of wood machining subjects as can be seen in the list of PhDs (Abdallah 2011; Aubert 1987; Bonduelle 1994; Bonin 2006; Boucher 2007; Collet 1984; Gauvent 2006; Jouffroy 1999; Levaillant 1978; Martin 1997; Méausoone 1996; Rougié 2009; Simonin 2010; Zerizer 1991 The Wood Machining Group (Groupe Usinage Bois) was established on the initiative of Rémy Marchal in 1993.

\section{The basic cutting process}

\subsection{General case of material cutting}

Most of the studies on material cutting have been dedicated to isotropic, homogeneous materials such as metals (Childs et al. 2000; Pomey 1970; Trent 2004; Zorev 1966) or plastics (Kobayashi 1967), with the exception of Atkins (2009), who wrote a general book on all kinds of material cutting.

Physical and mechanical study of the interaction between a tool and a material is the basis for analysing the cutting process (Atkins 2009). A tool can have a single edge or multiple edges acting simultaneously or one after the other in different directions. Most fundamental studies have been done on the simplest case of a single-edged tool whose orientation is perpendicular to its movement relative to the material piece, i.e., orthogonal cutting. Oblique cutting (Fischer et al. 2011) means that the angle between the tool edge and the cutting direction is less than $90^{\circ}$ (down to $10^{\circ}$ in some cases).
Table 2 Number of publications dealing with metals or wood machining in the period 1984-2014

\begin{tabular}{lrlrll}
\hline Publications & Metals & Percent & Wood & Percent & Metals/wood \\
\hline $1984-1993$ & 174 & 9 & 55 & 16 & 3.2 \\
$1994-2003$ & 638 & 32 & 91 & 26 & 7.0 \\
$2004-2014$ & 1158 & 59 & 203 & 58 & 5.7 \\
$1984-2014$ & 1970 & 100 & 349 & 100 & 5.6 \\
USA & 387 & 20 & 43 & 12 & 9.0 \\
China & 301 & 15 & 13 & 4 & 23.2 \\
Germany & 152 & 8 & 30 & 9 & 5.1 \\
England & 129 & 7 & 24 & 7 & 5.4 \\
Canada & 82 & 4 & 21 & 6 & 3.9 \\
Japan & 76 & 4 & 58 & 17 & 1.3 \\
France & 76 & 4 & 45 & 13 & 1.7 \\
Sweden & 71 & 4 & 10 & 3 & 7.1 \\
\hline
\end{tabular}

Web of knowledge, using keywords: "wood cutting" or "wood machining" or "cutting of wood" or "machining of wood" for wood, "metal cutting" or "metal machining" or "cutting of metals" or "machining of metals". Number of publications, $\%$ per main country only for the period 1984-2014 and ratio of number between metals and wood

\subsubsection{Orthogonal cutting parameters (Fig. 1)}

The wedge angle $(\theta)$ and the length of the cutting edge characterise the sharp tool geometry while the rake angle $(\alpha)$, depth of cut and cutting speed are sufficient to define the relative position of tool and material piece. The clearance angle $(\zeta)$ is the result of the relation $\theta+\alpha+\zeta=90^{\circ}$. Orthogonal cutting can be proceeded at a constant depth of cut (the usual case for basic studies) or at an increasing or decreasing depth of cut (in the case of rotary movement of the tool, for example).

For all materials studied in orthogonal cutting at a constant depth of cut, a range of depth of cut exists, for a given combination of rake angle and cutting speed, leading to a continuous chip flow (Alauddin et al. 1995; Thibaut 1988) and the tool edge is kept in contact with the material. The main observed physical phenomena are:

- creation of a new free surface in the material (Atkins 2003)

- a localised narrow shearing zone of plastic deformation close to a plane (Fig. 1), defined by the angle $\phi$ (shearing

Table 1 Number of oral communications at International Wood Machining Seminar (IWMS) during the period 1967-1985, \% per main country

\begin{tabular}{|c|c|c|c|c|c|c|c|c|}
\hline IWMS 67-85 & USA & Germany & Canada & Sweden & Norway & France & Japan & UK \\
\hline 149 & 65 & 16 & 15 & 14 & 14 & 8 & 7 & 5 \\
\hline $100 \%$ & $44 \%$ & $11 \%$ & $10 \%$ & $9 \%$ & $9 \%$ & $5 \%$ & $5 \%$ & $3 \%$ \\
\hline
\end{tabular}




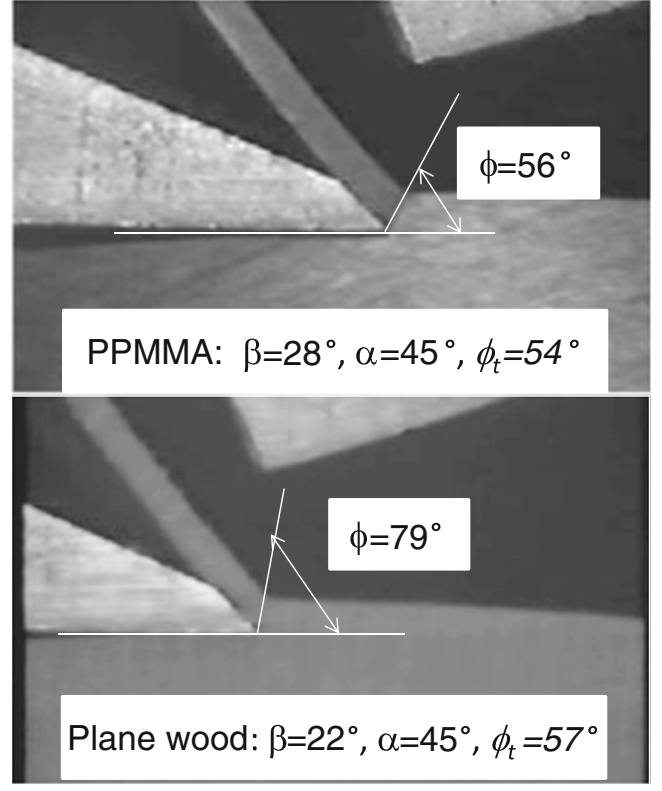

Fig. 1 Evidence of a narrow shearing zone for continuous chip formation (from Thibaut 1988). Top machining of polymer (PMMA), bottom wood machining (Plane wood). $\phi$ is the angle between shearing plane and cutting direction (shearing angle) measured on the picture, $\phi_{\mathrm{t}}$ is the theoretical shearing angle calculated from Merchant's theory using friction angle $\beta$ coming from experiment (Thibaut 1988), $\alpha$ is the tool rake angle, $\beta$ is the friction angle between tool and material

angle) it makes with the cutting direction, running between the tool tip and the free material surface (Gindy 1978; Mallock 1881; Thibaut 1988)

- compressive stresses acting on the shear zone (Gindy 1978; Thibaut 1988)
- contact zones between tool faces (rake face and clearance face) and material, where friction between the tool and the material occurs, often called secondary shear zones (Artozoul et al. 2014; Atkins 2009).

- chip thickness $h$ after cutting and some delay (possible viscoelastic recovery) is most of the time different from the depth of cut $t$ (usually bigger), thus chip length is usually shorter than the path of the tool (Mallock 1881). The swelling ratio $h / t$ is closely linked to the shearing angle $\phi$ (Gindy 1978; Jouty 1955).

- chip curls above the rake face with a more or less pronounced curvature (Jouty 1955; Kobayashi 1967; Thibaut 1988)

- $\quad$ outside of the highly stressed zone (around the tool tip) the material piece undergoes small elastic strains, the integration of which can lead to significant displacement where the cutting occurs (Decès-Petit 1996; Hoadley 1962; Kobayashi 1967; Thibaut 1988)

\subsubsection{Cutting forces (Fig. 2)}

The total force exerted by the tool on the material (Marchal et al. 2009) can be broken down into two components using different geometrical sums: (i) cutting force $\mathrm{F}_{\mathrm{C}}$ and thrust force $\mathrm{F}_{\mathrm{T}}$, respectively, parallel and perpendicular to the cutting direction, (ii) rake force $F_{A}$ and clearance force $F_{D}$ representing, respectively, the resultant forces exerted by the tool rake face for chip removal and by the tool clearance face rubbing on the cut piece just behind the tool tip.
Fig. 2 Cutting geometry and forces. $\alpha$ is the rake angle, $\phi$ is the angle between shearing plane and cutting direction, $\beta$ is the friction angle between tool and material, $\theta$ is the wedge angle of the tool, $\zeta$ is the clearance angle, $h$ is the chip thickness, $t$ is the cutting depth of cut, $F_{\mathrm{C}}$ is the cutting force parallel to cutting direction, $F_{\mathrm{T}}$ is the thrust force orthogonal to cutting direction, $F_{\mathrm{A}}$ is the rake force exerted by rake face on chip, $F_{\mathrm{D}}$ is the clearance force exerted by clearance face on material

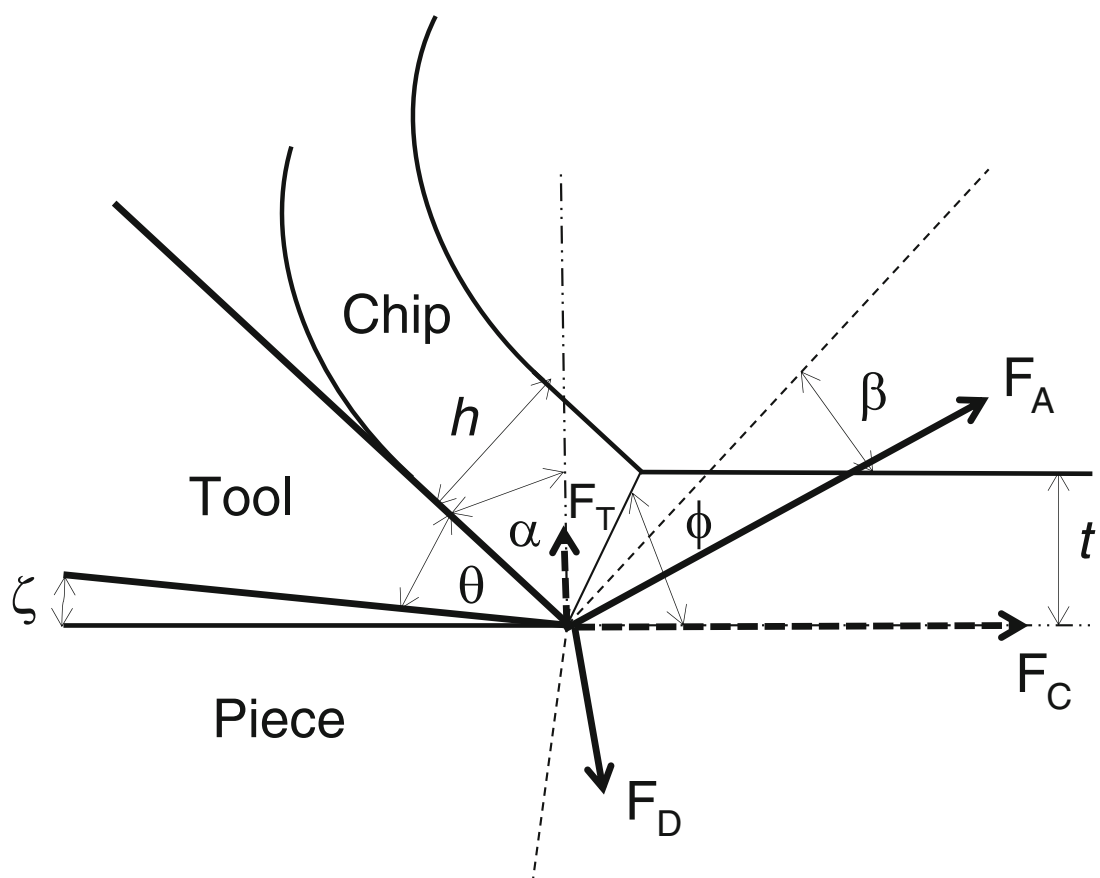


The friction exerted by a chip on the rake face, and material on the clearance face, is usually represented by a coulomb model described by the constant friction angle $\beta$, which is useful to relate the paired components $\left(\mathrm{F}_{\mathrm{A}}, \mathrm{F}_{\mathrm{D}}\right)$ to the available paired components $\left(\mathrm{F}_{\mathrm{C}}, \mathrm{F}_{\mathrm{T}}\right)$ with the aid of a $2 \mathrm{D}$ force transducer. In material cutting, freshly produced material surface rubs on tool faces, and it is suitable to use measured forces in cutting experiments to estimate the friction angle, provided the paired components $\left(\mathrm{F}_{\mathrm{A}}, \mathrm{F}_{\mathrm{D}}\right)$ are correctly separated, if not, the friction angle will grow to unrealistic values for a small depth of cut (Thibaut 1988).

$\mathrm{F}_{\mathrm{A}}$ can be broken down into two components: normal (compressive force) and parallel (shearing force) relative to the rake face: $\left(\mathrm{N}_{\mathrm{A}}, \mathrm{S}_{\mathrm{A}}\right)$ (Fig. 3).

Finally, force $\mathrm{F}_{\mathrm{A}}$ exerted on the main shearing plane can also be broken down into two components: a normal (compressive force) to the plane $\mathrm{F}_{\mathrm{N}}$ and a parallel (shearing force) to the plane $\mathrm{F}_{\mathrm{S}}$.

\subsubsection{Merchant's model}

A simple and robust plastic shear plane model with coulomb friction was proposed by Ernst and Merchant (1941) for metal cutting and is still widely used as a first approach to orthogonal cutting. Three necessary considerations should be added: (i) energy spent in the specific work of surface separation, which is compulsory to create a new surface with a cutting operation, is significant (Atkins 2009); (2) clearance force $F_{D}$ is always significant, as there is always a small wear facet on the clearance face, although it does not contribute to chip formation (Thibaut 1988); (3) the compressive stress field on

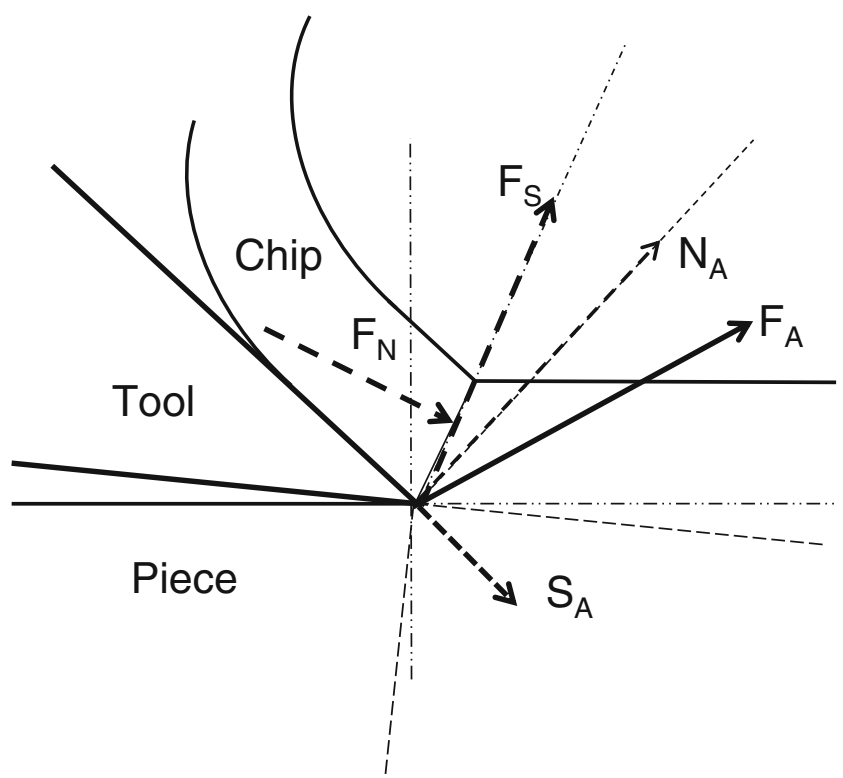

Fig. 3 Force exerted by the tool on the chip $\left(\mathrm{F}_{\mathrm{A}}\right) . N_{\mathrm{A}}$ is the normal (compressive) rake force, $S_{\mathrm{A}}$ is the parallel (shearing) rake force, $F_{\mathrm{N}}$ is the normal (compressive) force to the shearing plane, $F_{\mathrm{S}}$ is the parallel (shearing) force to the shearing plane the shear zone is not necessarily uniformly distributed from the bottom to the top of the chip (Thibaut 1988).

The main qualitative results of this model are (i) shearing angle $\phi$ is linked to rake angle $\alpha$ and friction angle $\beta$ only: $\phi=\pi / 4+\alpha / 2-\beta / 2$; (ii) the swelling ratio depends only on rake angle $\alpha$ and shearing angle $\phi: \mathrm{h} / \mathrm{t}=\cos (\alpha-\phi)$; (iii) rake force $\mathrm{F}_{\mathrm{A}}$ increases with depth of cut in a linear way (Fig. 4) - its intercept with zero depth of cut is positive and directly linked to the specific work of surface separation while the slope of the straight line is linked to energy dissipation within the main shearing phenomenon (Atkins 2009; Thibaut and Beauchêne 2004).

Outside of the depth of cut range for continuous chip flow, there are two different discontinuous chip flow types:

- for smaller depths of cut, the mean compressive stress exerted on the chip section grows sharply (because of the positive intercept cited above) and it can exceed the compressive strength of the material;

- for larger depths of cut shearing flow ceases to be the driving phenomenon and significant cracks appears, with a more or less periodic discontinuous formation of the chip.

\subsection{Woodcutting}

A great deal of work has been done in different countries that will not be related here. Peter Koch's books (1964 1964, 1985) give a very large overview of North American works by well-known authors such as Franz, Mc Kenzie and Stewart. There are many strong differences between metal or plastic cutting and woodcutting: anisotropy, high porosity, sensitivity to moisture and temperature of wooden material, large stiffness differences between the tool and material, and tool wear mechanisms.

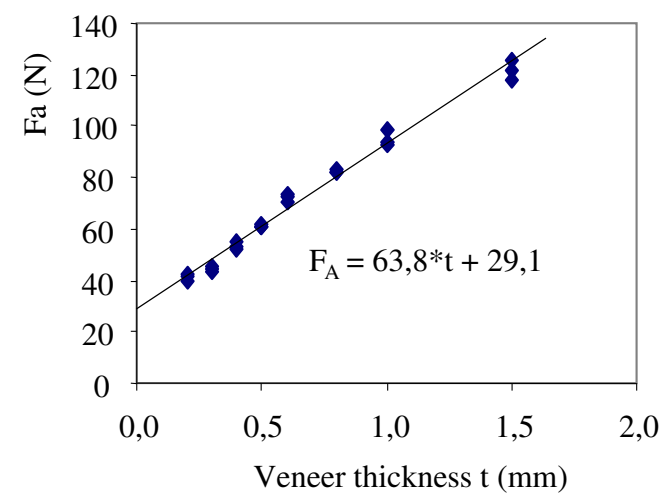

Fig. 4 Variation of cutting force with chip thickness in $0-90^{\circ}$ cutting mode (from Beauchêne 1996); the width of the chip is $20 \mathrm{~mm}$. Force intercept with zero thickness is linked to specific work of surface separation which is dissipated whatever the very low thickness of chip 


\subsubsection{Anisotropy}

In some cases, metals or plastics have a significant anisotropy resulting from the material production (cold rolling or plastic extrusion). While measuring some mechanical property with different loading directions, there will be changes of values with a maximum ratio ranging between one and two (Gindy 1978), but for solid wood this ratio is an order of magnitude more, ranging from ten to twenty. Therefore, anisotropy is the first parameter to deal with in woodcutting. As early as 150 years ago, Richards (1872) stated that "Cutting wood consists of two distinct operations: cross severing the fibre and splitting the fibre parallel with its lamination"; "The greatest amount of power and the best edges are needed for cross severing the fibre" and "The cross severing of the fibre must precede the splitting process". This separation into two cutting types is well explained by the huge difference in energy spent on the specific work of surface separation between surfaces perpendicular to the fibre and surfaces parallel to the fibre (Jeronimidis 1980; Triboulot 1981).

It is well known that splitting alone (after cross cutting in bolts) can be used to produce timber parts with a very low energy dissipation. There are also many wood shaping operations that combine cutting and splitting in the way described by Richards: first by severing the fibre, and second by splitting a more or less big flake, using axes, chisels or gouges.

Later, Kivimaa (1950) divided the "splitting the fibre parallel to its lamination" into two modes (B and C), using three basic cutting modes A, B and C. McKenzie (1961) made use of two-angle notation to name these three basic modes: $90^{\circ}$ $90^{\circ}$ (A mode), $90^{\circ} / 0^{\circ}$ (B mode) and $0^{\circ} / 90^{\circ}$ (C mode). The first number is the angle between the tool edge and the direction of the fibre, and the second is the angle between the cutting direction and the direction of the fibre (Fig. 5).

In $90^{\circ} / 90^{\circ}$ mode, the fibre is severed by the tool edge, the LT (or LR) shearing mode is dominant and the specific work of surface separation is very high.

In $90^{\circ} / 0^{\circ}$ mode, the fibre should "climb" on the rake face, the LT (or LR) shearing mode is dominant and the specific work of surface separation is low.
In $0^{\circ} / 90^{\circ}$, the fibre should "roll" over the rake face, the TR shearing mode is dominant and the specific work of surface separation is low.

Due to frequent small deviations of grain angle $\gamma$, even on clear wood specimen, angles are not always strictly $90^{\circ}$ or $0^{\circ}$. This is of particular importance for the $90^{\circ} / 0^{\circ}$ mode. The $0^{\circ}+$ $\gamma$ situation is called cutting with the grain while $0^{\circ}-\gamma$ situation is called cutting against the grain. There are very significant differences in crack occurrence between these two situations (Goli 2003; Goli et al. 2005).

A third angle can be used to indicate the angle between the cutting direction and the tangential (ring limit) direction. Using R or T as an index $\left(90^{\circ} / 90^{\circ}\right.$, for example) allows six basic cutting modes to be identified, but often the differences between the $\mathrm{R}$ and $\mathrm{T}$ cutting direction are not that important and additionally most pieces have varying orientations in the RT plane. In the third mode, $0^{\circ} / 90^{\circ} \mathrm{T}$ (peeling), the angle between the ring limit and the cutting direction, be it positive or negative, has a large impact on check occurrence (Movassaghi 1985).

Due to the fact that in real cutting world operations (knot occurrence for example), all intermediate orientations between basic cutting modes can appear, specific cutting tests, such as Goli's wheel (Goli 2003), have been used in order to estimate cutting force variations and check occurrence in all possible cases (Costes et al. 2004; Goli et al. 2005, 2010).

\subsubsection{Porosity and density}

As with honeycombs or foams, wood is characterised by a very high porosity (from a $10 \%$ to more than $90 \%$ proportion of voids between Snake-wood and Balsa, respectively). Continuous media hypothesis, such as volume conservation during high-strain cases, is no longer valid. At the fibre level, porosity causes the cell wall to collapse under tool tip action, with the consequence of a rubbing action from the clearance tool face on the cell walls, whatever the clearance angle. The specific mechanical behaviour typical of foams or honeycombs applies to wood (Gibson and Ashby 1999).
Fig. 5 Basic cutting modes in wood cutting (from McKenzie 1961). The first number is the angle between tool edge and fibre direction, the second being the angle between cutting direction and fibre direction

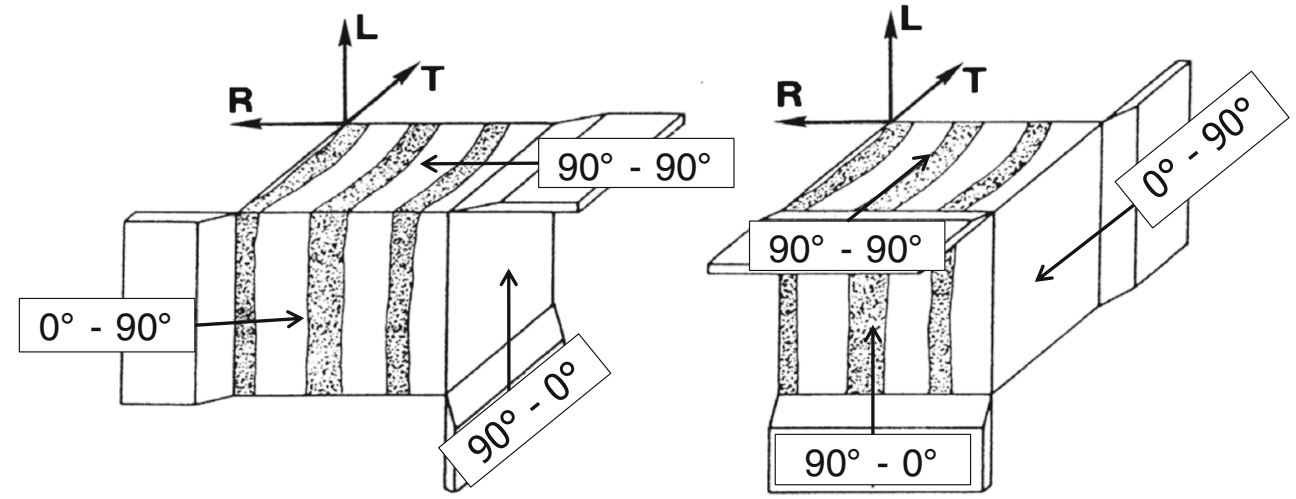


Density $\rho$ is strongly related to porosity for such materials and is always the first factor of influence on mechanical properties (MP). Power law relationships such as $\mathrm{MP}=\mathrm{K}^{*} \rho^{\beta}$ are usually the best regression functions. In the case of woods with strong anisotropy, loading direction should always be taken into account. In the case of axial loading, the power law exponent $\beta$ is always very close to 1 (Guitard 1987), both for the elastic modulus and strength in compression or flexion. For transverse compression loading, this exponent is closer to 2 (Bardet et al. 2003). For both longitudinal shear (LT or LR) and rolling shear (RT), the exponent is again near 1 (Bardet et al. 2003; Guitard 1987). However, for transverse strength and the specific work of surface separation, the exponent is lower than 1 (around 0.7 in Bardet et al. 2003).

Moreover, the maximum strain at rupture maintains rather low values (a few \%) in axial loading while in transverse compression or rolling shear loading it should be ten times higher (Beauchêne 1996).

As a consequence, in a given regime for each basic woodcutting process defined by its cutting angles and depth of cut, there are always good to very good relationships between cutting forces and wood density. For very inhomogeneous species (most softwood), this relation is still true in early or late wood, except for transition cases where the ring limit stays within the chip thickness (Eyma et al. 2001, 2004; Mothe 1988; Movassaghi 1985; Thibaut 1988).

\subsubsection{Chip formation and surface quality}

For every woodcutting mode, there are more or less large working zones, defined by ranges of rake angle, depth of cut, cutting speed, available for industrial operations producing a "clean cut" with adequate surface quality (Chardin 1958). They can be defined by standard methods such as the "tool-material couple" (Martin 1992; Méausoone et al. 2001) used for metal machining and as those defined in standards (AFNOR 1994). The working zones include continuous and discontinuous chip flow provided that the surface quality fits the future uses of the piece.

In the case of continuous chip flow, surface quality is usually very good, but the range of depth of cut for this chip type is often narrow and, sometimes, a continuous ribbon is hard to manage on machine tools. Ultimately, discontinuous chip flow is usually more frequent than continuous chip flow. The former can be studied as a "normal" cutting operation (for $90^{\circ} / 0^{\circ}$ mode, see Franz 1958; Koch 1964) or be considered as a limited case of continuous chip flow for lower and higher ranges of chip thickness in given cutting conditions (Thibaut 1988). In both approaches, three main chip types are defined: continuous chips produced by a shearing action (Franz type 2), chips produced at lower thicknesses with a significant compression buckling of the chip ahead of the tool tip (Franz type 3) and chips produced at higher thicknesses with a significant crack opening ahead of the tool tip (Franz type 1).

For discontinuous chip flow, there is always the creation of new surfaces other than the wanted machined surface, caused by crack occurrence and propagation (knife cracks), usually in directions different from the cutting direction. Often cutting energy is lower than what would be expected for continuous chip flow (Atkins 2009) because energy spent in crack opening is less than energy dissipated in chip deformation (Merhar and Bučar 2012)

Depending on knife crack geometry, surface quality will be more or less degraded (Atkins 2009).

There are significant differences between the fundamental modes for the chip formation process (Franz 1958; McKenzie 1961; Stewart 1971; Woodson and Koch 1970).

$0^{\circ} / 90^{\circ}$ mode Veneer cutting (without a pressure bar) is the perfect case of this mode where a long chip (veneer) is the final product. The three chip types are well defined. Continuous chip flow produces the best veneers and the range of continuous chip flow depends on density (from 0.2 to $1.0 \mathrm{~mm}$ for medium-density timbers) and can be enhanced to 2 or $3 \mathrm{~mm}$ with the use of a pressure bar (Boulloud 1972; Kinoshita 1983; Leney 1960; Thibaut 1988). The shearing angle is high (around $80^{\circ}$ ) and cannot be predicted with the Merchant theory (Fig. 1), while there is no shortening of the chip (Thibaut 1988). Both the specific work of surface separation and compressive strength are low whatever the direction of crack propagation or compression loading.

For a small depth of cut in low density woods, the mean compression stress on the main shearing plane exceeds the limit value where very large deformation occurs due to transverse cell wall buckling (Fig. 6). A bundle of material is compacted ahead of the tool tip until separation can occur with small cracks above and beneath the cutting direction together with a quick swelling back of the bundle, as in the movement of an accordion. This was called the Horner effect (Mothe 1988) with reference to Yvette Horner, a famous artist who played the accordion on the Tour de France publicity fleet in the late 1950s and early 1960s (Horner 2005).

For greater depth of cut, the tensile stress concentration at the tool tip begins to be able to initiate a mode 1 sudden crack, more or less in the cutting direction (Fig. 7b). The loading conditions on the rake face change immediately favouring flexion of the chip and crack propagation in a direction more perpendicular to the cutting path without a complete break of the chip. This cracking process is nearly periodic (with a distance between cracks more or less in proportion to the depth of cut) for homogeneous species like poplar or Okoumé. Lathe check phenomenon is largely influenced by wood anatomy (Dupleix et al. 2013). Distribution of both depth and occurrence of checks, measured on a large experimental material with a special apparatus produced by SMOFC (Pałubicki et al. 
Fig. 6 Minimum chip thickness in $0-90^{\circ}$ cutting mode (from Thibaut 1988). Left uniform buckling compressive stress due to normal force to the shearing plane. Right water expulsion on side of the wood prove the buckling of wood structure in transverse compression

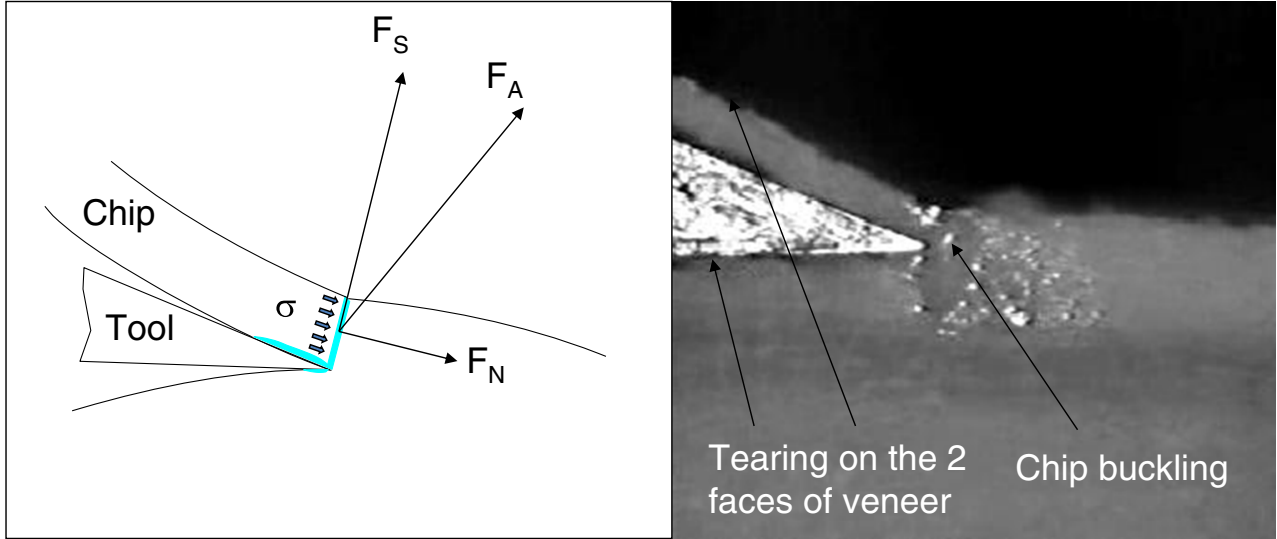

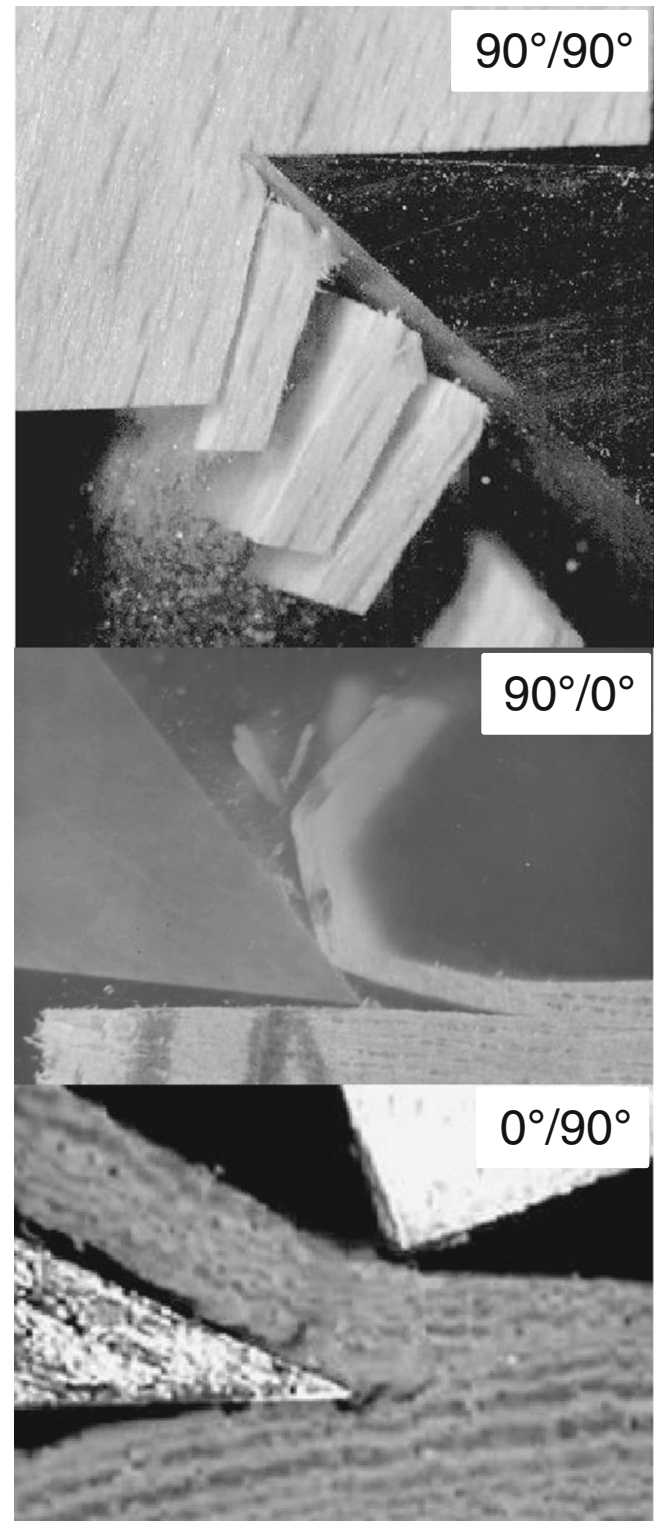

Fig. 7 Discontinuous cutting with crack opening. a top: $90-90^{\circ}$ cutting mode (Photo Pfeiffer R). b middle: $90-0^{\circ}$ cutting mode (Photo Chardin A). c bottom: $0-90^{\circ}$ cutting mode (Photo Thibaut B)
2010), fit a Gaussian curve. As long as the veneer can be manipulated, rather deep cracks are allowed. The consequences of lathe checks for plywood (Daoui et al. 2011) and for laminated veneer lumber (LVL) (Pot et al. 2014) were discussed in the literature.

$90^{\circ} / 0^{\circ}$ mode Dominant in flat plaining, this mode is also frequent in longitudinal sawing (associated with the $90^{\circ} / 90^{\circ}$ mode). The specific work of surface separation is low but compressive strength in the fibre direction is high; thus, type 3 chip formation only occurs with a rather small rake angle, while type 1 chip formation is frequent. Type 2 continuous chip flow yields excellent surfaces and rake angles that promote the formation of this kind of chip can be predicted through force analysis (Stewart 1977). Type 2 chip occurs for rather small depth of cuts (10 to $200 \mu \mathrm{m}$ in Ohtani 2007). For usual depths of cut, there is a sudden mode 1 crack opening, with a rather significant crack length directed along the grain (Fig. 7c). Flexion is then the dominant mechanism and a small beam is produced by the crack and breaks by a rupture orthogonal to the fibre.

$90^{\circ} / 90^{\circ}$ mode This mode was studied for optimisation of the saw tooth (Chardin 1957, 1958). It is very often used when preparing thin slices for anatomy studies as it allows continuous chip flow in the range of 1 to $50 \mu \mathrm{m}$, depending on rake angle. The cut surface is orthogonal to fibre, thus specific work of surface separation is very high and crack opening will always occur orthogonal to the cut surface. Moreover, compression in the main shearing zone is in a transverse direction, with low compressive resistance decreasing very rapidly with density. For low density woods, unless high rake angles are being used, wood will crush under compression before fibres are severed, promoting longitudinal cracks under the cut surface. After compacting, a bundle of fibres will be severed and the process is reproduced on a more or less periodic basis. For higher thicknesses and typical rake angles (around $40^{\circ}$ ), shearing cracks occur parallel to the grain and the chip is 
fragmented like a pack of cards (Pfeiffer et al. 2014), which is welcomed in chipping operations (Fig. 7a).

\subsubsection{Sensitivity to moisture content and temperature}

Woods are both porous and made of moisture- and temperature-sensitive polymers. As regards moisture content, for cutting, two contrasting situations above and below the fibre saturation point (FSP) are encountered:

Green wood, as it is in the tree and for most primary conversion. There is free water inside the porosity (on average, half the voids available are filled with free water in green wood) and the cell wall polymers hold around $30 \%$ adsorbed water relative to their anhydrous mass. This means that green wood is naturally cooled by free water.

Air dried wood, which is the case for most secondary processing. There is no more water in the voids and the moisture content of cell walls is in equilibrium with ambient air (between 6 and $18 \%$ ). Contrary to metals, dry wood is a bad conductor of heat and most of the heat generated by the cutting process will be kept in the area surrounding the cutting edge, leading to the risk of the wood burning and high temperatures for the tool tip (Chardin 1968a, b).

Aside from this direct effect of moisture content, there are also changes in the mechanical behaviour of wood throughout the range between $6 \%$ and FSP. Changes are greater for strain at maximum stress than for elastic modulus or strength whatever the loading mode, on one side, for transverse loading mode than for axial loading mode, whatever the property measured, on the other side.

Moreover, for green wood, the glass transition temperature is rather low (between 50 and $70{ }^{\circ} \mathrm{C}$ ). Heating green wood above these temperatures leads to changes in mechanical behaviour even greater than changes from dry to green conditions (Bardet et al. 2003); there is much higher maximum strain before rupture and much lower modulus of elasticity and strength, especially in transverse loading (Beauchêne 1996). There is a kind of trade-off between the changes in all the meaningful properties for the $0^{\circ} / 90^{\circ}$ cutting mode. As a result, lathe check amplitude decreases when temperature rises at constant settings (Dupleix 2013).

On the contrary, in the case of frozen logs (Lundberg and Axelsson 1993), water is in a solid state, thus changing both cutting forces and chip formation. Freezing wet wood in microtome cutting can be a solution for very soft material (cambial zones).

\subsubsection{Friction between wood and tool material}

Friction between wood and tool faces is strongly dependent on the availability of natural lubricant inside the wood itself, such as resins or waxes located in specialised oil cells or resin ducts in species from different families, such as Pinaceae or Lauraceae. Some woods, e.g., Lignum vitae, have a friction angle as low as Teflon (Bowden and Tabor 1968), and Louro vermelho have a friction angle half the usual value for other tropical woods (Beauchêne 1996).

For dry wood, there seems to be little influence on friction angle from temperature or cutting speed (Murase 1979). For green wood, temperature shows little influence (Beauchêne 1996) but for a change of cutting speed from $1 \mathrm{~mm} / \mathrm{s}$ to $1 \mathrm{~m} /$ $\mathrm{s}$ (Fig. 8), the friction angle decreases from $30^{\circ}$ to $15^{\circ}$ in a logarithmic linear trend (Thibaut 1988).

\subsubsection{Tool wear}

During the cutting process, tool wear will appear with three main aspects (Klamecki 1979):

- Impact wear, minute breaks due to shocks (e.g. due to knots) and brittleness of the tool tip material (Chardin 1968a, b). This can be promoted by the coupling of stress and corrosion actions. The long-term tiny cracks will grow and notches appearing in the cutting edge will require a long restoration of the sharp tool.

- Corrosive wear, acidity and extractive content acts as corrosive agents against metals, and crack occurrence at the tool tip can be promoted by stress corrosion mechanisms (Darmawan et al. 2012; Gauvent et al. 2005; Klamecki 1979; Porankiewicz et al. 2008).

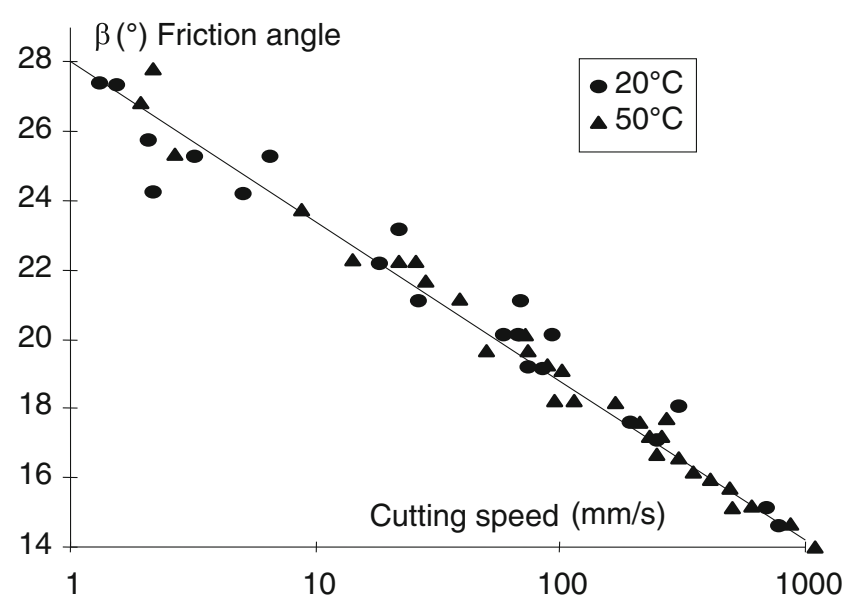

Fig. 8 Evolution of friction angle with cutting speed for green wood (chestnut) at 2 temperatures (from Thibaut 1988). It should be noted that the bottom left of the graph is not a true origin (neither the ordinate nor the abscissa is zero), but the axes are shown intersecting by commodity; abscissa (cutting speed) is used in logarithmic scale, but the actual values are put in legend 
- Abrasive wear, changes in tool tip geometry (edge radius, very local changes in rake or clearance angles) induced by progressive grinding of the tool edge, removing material from the tool with a shearing action of the friction forces (Chardin 1962, 1968b). Three main factors influence the speed of abrasive wear: (i) friction forces per unit surface of tool face rubbing on wood, which depends mainly on wood density and moisture content but not so much on chip thickness (Chardin 1962); (ii) shear strength of tool material, linked to its hardness, using hard materials with high temperature resistance (ceramics for example), is a way to limit wear by grinding, but the tool edge is very brittle and large rake angles are not possible (Chardin 1962); (3) the occurrence of very hard particles included in the wood substance which then acts as a kind of grindstone. This is the case in many silica hyper-accumulating tropical species. Usually silica content in woods accounts for less than $200 \mathrm{ppm}(0.02 \%)$, but there are species with silica content as high as $20,000 \mathrm{ppm}(2 \%)$. For common woods, silica content has no influence on wear, but for these siliceous woods wear can be a hundred times faster (Chardin 1962), and the use of stellite-tipped tools or carbide inserts is essential (Chardin 1962).

\subsubsection{Contrast in stiffness between tool and wood}

The stiffness of the tool, i.e., tool tip displacement under resistant transverse cutting force $\mathrm{F}_{\mathrm{T}}$, is often much greater than wood piece stiffness, i.e., elastic wood surface displacement just ahead of tool tip under cutting force $\mathrm{F}_{\mathrm{T}}$ (Decès-Petit 1996; Hoadley 1962; Sugiyama 1971a, b; Thibaut 1988). If $\mathrm{F}_{\mathrm{T}}$ is directed towards the inside of the wooden piece, there will be an elastic downward displacement of the wood surface, cutting thickness will be lower, the elastic recovery after cutting will induce more rubbing on the clearance face and the fresh cut surface will rest at a level higher than that which was scheduled by the depth of cut. This difference in surface level is called an "over-levelled surface". For the opposite conditions, $\mathrm{F}_{\mathrm{T}}$ is directed towards the outside of the wooden piece, all the results are opposite and there is an "under-levelled surface". The change of regime from under-levelled surface to over-levelled surface can have a large influence on the cutting process due to unavoidable mechanical play in machines and it is better to stay in a regime of a low underlevelled surface.

\subsubsection{Wood diversity}

There is a very great diversity of wooden species (around 30, 000 in the world), yet the tool-material couple experimental approach (AFNOR 1994), used to determine the working zone of a cutting tool for a particular operation, cannot be done for all of them. A way to deal with this problem is by using existing databases of wood properties (anatomical, chemical, physical and mechanical) in order to acquire information on silica content, extractive nature and content, density, elastic modulus, strength and toughness (Beauchêne 1996; Eyma 2002). Unfortunately, there are rather few data on shearing or toughness and transverse directions and green wood is less documented. This is a huge challenge for the future in view of a better utilisation of timber biodiversity.

\section{Primary conversion}

After felling and cross cutting trees into logs, a wide array of machining operations is needed in order to provide useful wooden elements for use in industry: timber, veneers, particles or chips. Green wood sawing, veneer cutting and chipping are basic operations consisting of the separation of wooden parts in the native log.

\subsection{Growth stresses and primary conversion}

Growth stresses accumulated in the tree during its building by wood growth have long been known as a putative problem for tree felling, cross cutting, log heating or log sawing (Kubler 1987; Saurat and Guéneau 1976). Basic research programmes have been dedicated to the mechanics of stress accumulation (Alméras et al 2005; Alméras and Fournier 2009: Fournier et al 1990) and the thermally-activated expression of locked-in stresses by heating (Gril et al. 1993). Large field campaigns of in vivo measurements of peripheral maturation strains were done on different species such as pine, beech, chestnut and poplar (Castéra et al. 1994; Fournier et al. 1994; Yang et al 2005) in order to assess the possible influence of forest management on growth stress values (Ferrand 1982; Jullien et al. 2013; Polge 1981).

It was shown that cutting problems linked to growth stresses mostly concern angiosperms using tension wood which generates very high tensile stress on the upper side of the log in order to restore verticality. Gymnosperms using compression wood to generate compression stress on the lower side of the log for the same mechanical purpose give few problems during primary conversion, but big difficulties during drying due to the very high longitudinal shrinkage of compression wood (Gardiner et al. 2014; Jullien et al. 2003; Radi and Castera 1992).

It is thus important to identify large sectors of tension or compression wood on logs being cut for timber. Compression wood is often associated with a large dissymmetry of growth between two sides and can be detected with different image techniques such as $2 \mathrm{D}$ or $3 \mathrm{D}$ imaging or the use of nearinfrared spectroscopy (Altaner et al. 2009; Hapca 2004; 
Thomas 2000; Watanabe et al. 2012). Logs with a large section of tension wood can have rather symmetric growth, making tension wood harder to detect (Barbacci et al. 2008; Clair et al. 2003).

With information on large sectors of reaction wood in a log, simple models of growth stress distribution can be used in order to simulate timber warping resulting from sawing and to try to choose better sawing patterns (Ormarsson et al. 2009) or to predict the dimensional stability of plywood boards (Mothe et al. 2002). It can also be used to keep the proportion of heterogeneous boards containing both reaction and normal wood to the lowest possible level.

\subsection{Wood density, branching and primary conversion}

Depending on log geometry (taper, sapwood thickness and curvature) best sawing schedule can be predicted in response to market demand (Riesco-Muñoz et al. 2013). A branch in a tree always gives knots in timber. The diameter, position and orientation of this knot inside the board are of utmost importance for the mechanical properties (MOE and MOR) of timber (Roblot et al. 2008). Most of the mechanical sorting of timber in sawmills is based on 2D or 3D analysis of knot distribution (together with non-destructive measurement of MOE).

X-ray tomography was recently used to help predicting timber quality in relation to tree growth in the forest. Efficient software makes virtual sawing or veneer cutting of a $\log$ described by 3D tomography a reality (Longuetaud et al. 2007, 2012; Mothe et al. 2002; Roussel et al. 2014), opening the door to better sawing patterns in a sawmill for a known resource and a given market (Berglund et al. 2014). By using a simple geometrical transformation to simulate the veneering process, the tree stem description given by growth and yield simulation software (Dufour-Kowalski et al. 2012) allows the delivery of virtual maps of wood properties in veneers (grain angle and wood density) and prediction of the properties of secondary transformation products (Constant et al. 2003; Mothe et al. 2002).

\subsection{Timber sawing}

Sawing is the most universal way of getting timber in primary or secondary breakdown. Every saw is a collection of teeth on a blade. Handsaws were in use more than 10,000 years ago (Naylor and Hackney 2013). Frame saws were the first to be used in the industrial period, but band saws rapidly became dominant in primary conversion. Circular saws are common in the re-sawing of beams for boards and have become used more often in the primary conversion of small diameter logs. The different models of band saws are distinguished by the arrangement of the frame, the number of frames and the feature of the saw blade (single-cut or bi-cut) (Sales 1990).
In sawmilling using band saws, $90^{\circ} / 90^{\circ}$ is the main cutting mode. This has been studied from different aspects: optimisation of the teeth, optimised working zones, the correlation between cutting force and density, the cutting material of the saw blades and wear of the saw teeth (Chardin 1957, 1958, 1962, 1966, 1967a, b, 1968a, b). Many studies have been done on tropical species. Band saw performance was related to surface quality and productivity (Sales 1990). Blade tensioning as well as tilt and blade preparation was identified as major parameters (Rivat 1996). In Japan, the dynamic characteristics of band saws (Kimura et al. 1994) and saw blade vibration (Tanaka et al. 1981) have garnered much attention. Many $\mathrm{PhD}$ works were done in close cooperation with tool manufacturers to ensure the transfer of knowledge to industry.

Circular saws, besides implications for edging and cross cutting operations, are increasingly being used as saw heads. One of the main advantages is the resulting quality of the cutting operation in terms of thickness regularity and surface quality. Surface quality from sawing is a function of factors related to the process (such as the feed rate), factors related to the tooling system (such as the cutting angle) and factors related to the material (such as wood moisture, density or heterogeneity).

Considerable research has been done in North America (Schajer 1986) on the theory of critical velocity. The vibrations of the circular blade are the conjunction of several resonance modes and for each mode (Mote and Szymani 1977) the vibration is the superposition of two waves, one moving in the direction of rotation and the other in the opposite direction. This research investigates the possibility of reducing kerf losses by decreasing saw thickness, which affects its rigidity and thus its stability. The main parameters affecting saw stability are centrifugal forces, residual stresses from tensioning, blade temperature and lateral cutting forces. Finite element analysis was used to compute the dependence on these factors for bending deflexion of the circular saw (Chabrier 1997). The accuracy of saw kerf, timber surface quality and the safety of workers depends on the dynamic characteristics of the blade, its preparation in the workshop, teeth sharpening and characteristics of the machine (Orlowski et al. 2007). Another way to improve the sawing process is by looking for the best matching between cutting material and blade geometry (Simonin et al. 2009).

For small diameter trees, sawing following the log curve allows an increasing recovery rate compared to straight sawing (Hutton et al. 1987; Schajer 1985), and also increases the strength of sawn timber and limit timber drying deformations. Guided blades are recommended for this type of curve sawing. In Europe, unguided circular saw blades (Dietz and Plötz 2005) are used for curve sawing but each manufacturer has developed its own secret concept of curve sawing and it is difficult to find comparative publications on this subject. Very often chipper canters (Hernandez and Boulanger 1997; 
Lusth et al. 2013) are used to transform the log into a rectangular shape before it is sawn into boards.

\subsection{Veneer cutting}

In addition to basic studies on the $0^{\circ} / 90^{\circ}$ cutting mode (3.2), including lathe check occurrence, the role and settings of the pressure bar, wood heterogeneity and green wood heating, studies have been dedicated to the peeling operation itself (Hancock and Feihl 1980; Lutz 1974 and 1977; Mothe et al 1997).

Transient phases in rotary veneer cutting either at the beginning of peeling, after the roundup phase or after some interruption in the cutting process, can lead to large fluctuations of veneer thickness due to an over-levelled or underlevelled surface mechanism (3.2.7). The tool clearance angle is the regulating parameter of these phenomena (Decès-Petit 1996; Denaud 2006), and it should be the control in relation to changes in lathe depth of cut and changes in compression rate of the pressure bar. The design of new peelers with the motorisation of all settings (clearance angle, horizontal and vertical position of pressure bar) and the computer control of the process make it possible to achieve this regulation by using cutting parameters such as thrust force. Regardless, optimum settings are a difficult objective to attain and to maintain since the process constitutes a compromise for each log. For example, a high compression rate ensures unchecked veneers but makes transient phases longer (Denaud 2006).

It is a common practice for machine operators to listen to the "music of cutting" in order to know if things are going straight (Nagatomi et al. 1993). There are different frequency ranges associated with the cutting process: high frequencies for tiny cracks at the cell wall level, medium frequencies for lathe check occurrence, and low frequencies for knot severing or transitions from early to late wood. On-line sound measurements can be used to help the monitoring of the process (Denaud et al. 2005, 2007, 2012). Particularly, lathe check splitting can be measured using a microphone or an accelerometer. The most promising approach is to compare the cutting signals to references signals in order to remove background noise.

Heating the log prior to veneer cutting to the desired temperature is a tricky problem for industries. Both steaming and boiling, which are currently used, share problems of process management (hygrothermal recovery amplifying log end cracks, for example), water pollution and energy consumption (Marchal et al. 1993, 2004). The cutting process itself only occurs at the log periphery and usually only a few millimetres in depth have to be heated to the desired temperature. Research has been done in the laboratory to find alternative online heating systems for the log periphery, including microwave or infrared (Dupleix 2013; Dupleix et al. 2012). Since the heating transfer mode is mostly conduction, the idea of online heating should be discarded unless a new heating transfer solution can be developed.

Fifty years ago, peeling small diameter logs were considered nearly impossible for cutting reasons: bending of 2- to 3$\mathrm{mm}$-thick veneers at a small peeling radius was likely to dramatically increase lathe check occurrence. Both basic research (Thibaut 1988) and industrial developments in machine tool manufacture, mainly in Finland and the USA, have highlighted that (i) cutting radius is not a cutting problem even for around $2 \mathrm{~cm}$ values, (ii) for a very small radius, lathe settings should change a lot, (iii) the rotating drive using classical chucks did not allow peeling at very low diameters and peripheral driving should also be used, (iv) using small diameter logs means small lengths and thus very small log volume, so new computer aided peeling lines were developed in order to peel around ten logs per minute (Thibaut 2004).

The development of the Laminating Veneer Lumber (LVL) technology (Marchal 1989) in the 1980s opened a new market for veneer products issued from lower grade logs (Boury 1998) or from fast-growing plantation (Dobner et al. 2013; Rahayu et al. 2014), especially for small diameter logs (Hamilton et al. 2014; Luo et al. 2013). Associated with a small diameter peeling line, LVL technology gives the possibility of obtaining, in a short time, long structural beams from small logs.

\subsection{Green wood chipping}

Chip fragmentation is a very old way of shaping wooden objects using axes, chisels or gouges. It is a special case of the "cut \& split" operation managed in one single blow, with keen edges to sever the fibre and the blow energy being used to split a chip parallel to the grain. Today, canters are used in order to square or round logs in beams or poles (Hernandez and Boulanger 1997). These routers produce big chips (or flakes) which are directly usable by the pulp industry or automatically-fed wood boilers. The most important criterion is the thickness of the chips. A model of the chip fragmentation was used to design canters with the help of the finite element method (Pfeiffer et al. 2014).

Whole logs are increasingly being chipped through green wood milling for fuel uses (Pfeiffer et al. 2014).

\section{Secondary processing: Functionality of machined surfaces}

In the timber industry sanding and rotary cutting process such as plaining, routing or trimming are the main manufacturing processes used in finishing operations. Rotary cutting is defined as an orthogonal cutting in which the chip thickness is variable (Franz 1958). Sanding is a method by abrasion relatively easy to define, but chip formation in rotary cutting is 
much more difficult to apprehend. Hereafter, we will speak about rotary cutting in mode $\mathrm{B}\left(90^{\circ} / 0^{\circ}\right)$.

\subsection{Surface quality}

The improvement of the quality of machined surfaces has always been a major concern for wood industrial manufacturers. Early on, many researchers were interested in the concept of surface roughness (Koch 1964). Historically, the first works tried to gain a better understanding of how to measure the surface before looking to a particular functionality (Lemaster and Dornfeld 1982). It is possible to define a surface aptitude to coating as the result of the affinity of the product (paint, glue and varnish) to the substrate (wood). This is strongly dependent on the time and manufacturing history. Two sets of parameters are currently identified as influencing the quality of machined surfaces:

(i) those linked to the material: anatomy and physical, chemical and mechanical properties required to take into account the scale effects (Triboulot 1984; Triboulot et al. 1991). Thus, softwoods, mainly consisting of tracheids and the hardwoods, comprising fibres and vessels, present different surface roughness (Leban and Triboulot 1994).

(ii) those linked to the manufacturing process: vibrations of machines (Martin 1992), stability, wear of the tool cutting edges (Aguilera 2000), and the cutting conditions used (Khazaeian 2006). Thus, some authors have found that a higher cutting speed can, in some cases, improve the quality of the surface obtained from routing (Costes 2001).

Different surface irregularities (Eyma 2002) are conventionally ranked in 6 order numbers. The first and second orders respectively correspond to the shape deviation and waviness. Defects of the third and fourth order correspond to roughness defects. They are characterised by separated streaks and furrows of 0.02 to $0.5 \mathrm{~mm}$ and aperiodic defects, such as tearing or slots less than $20 \mu \mathrm{m}$ deep. Defects of the fifth and sixth order depend on the wood structure. These defects are in direct relation to surface functionality (De Moura 2006). In order to assess the quality of a wood machined surface, two sets of criteria are generally used: those linked to geometry and those related to the physics and chemistry of the surface (Gurau 2007; Rajemison 2013).

\subsection{Geometrical characterisation of surfaces}

The geometry-related criteria, especially visual and tactile criteria, were the first to be used (Marra and Syracuse 1943). They are subject to a standard (ASTM D1666 2011) and are still the only ways of assessment used by manufacturers, as they are directly correlated to consumer agreement (Coelho 2006; Goli 2003). Commonly-used criteria defined in the standard are raised grain, fuzzy grain, torn grain and chip marks (Goli 2003). Some authors have also used machining traces and splinter occurrence at the end of the wooden piece (Khazaeian 2006; Rajemison 2013). The disadvantage of this surface assessment comes from its subjectivity, because it is fully dependent on the assessor's perception (Marchal and Mothe 1994; Scholz et al. 2007). This is the reason why many studies have focused on different tools dedicated to surface roughness measurement (Sandak et al. 2004) using pneumatic methods (Mothe 1985), acoustic methods (Zhao et al. 1991), optical methods or mechanical sensors. The last method, although widespread today, is progressively being replaced by no-contact methods (laser perthometer, confocal scanning, etc.) that are able to prevent alteration of the surface during measurement (Ramananantoandro et al 2005). Surface roughness criteria for homogeneous materials such as steel are not very relevant for wood. These criteria are defined in standard NF EN ISO 42871998 and refer to height measurements in a given direction (Sandak and Negri 2005). The direction of measurement has a significant influence on the results obtained for wood (Sinn et al. 2009). A new available standard (ISO 25178-2 2012) allows these criteria to be defined in three dimensions (Ramananantoandro et al. 2013). However, if the difficulties related to wood anisotropy are solved with contactless devices, 3D surface roughness criteria and the use of a minimum sensing surface (Larricq et al. 2000), the problems related to signal filtering remain (Gurau et al. 2009). Moreover, it is still difficult to separate the influence of the wood structure itself and that of the machining operation, although for some authors, valley depth parameters seem particularly well suited to characterising the features of wood anatomy (Cool 2011; Khazaeian 2006). Many studies have focused on the relationship between roughness parameters and consumer visual tactile perception (Fujiwara et al. 2005; Ramananantoandro 2005; Ramananantoandro et al. 2013), both on medium-density fibreboard (MDF) and sanded solid wood. Some roughness parameters linked to peak and valley configuration (SRk or SRpk in the ISO standard for surface roughness analysis) show significant correlation with perception (Fig. 9), but it is generally better to combine many of them. Nevertheless, a tremendous amount of work remains to be done to develop 3D surface roughness criteria better correlated to consumer perception for wooden products. Moreover, many current studies deal with the relationship that may exist between these roughness parameters and the functionality of machined surfaces. Many questions remain unanswered: (i) what are the criteria to consider for each surface function, (ii) should these criteria be different from one species to another, (iii) how should the settings of machining parameters be optimised according to these criteria? 


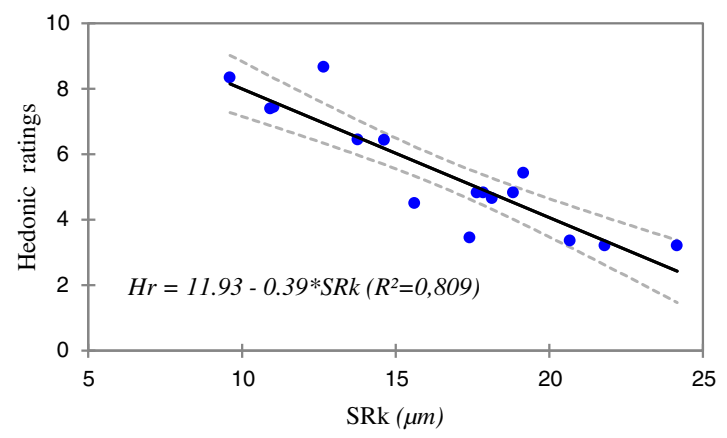

Fig. 9 Relationship between hedonic ratings (on a 10 points hedonic scale, where score 1 means "dislike extremely" and 10 means "like extremely") and roughness parameters a SRk, b SRpk obtained in a

\subsection{Physical and chemical characterisation of surfaces}

This second type of characterisation is used to characterise surface affinity with glue or coating films. The needed criteria are linked to surface physical-chemical properties which are strongly influenced by material, machining processes, temperature and surface ageing (Back 1991). Surface ageing, defined as the exposure time to given environmental conditions, has been the subject of many studies (Cool 2011). Long storage times cause surface oxidation and often some chemical modification (Sernek et al. 2004) by extractive migration (more active when wood is subject to hygrothermal treatments) or by contaminants such as volatile organic compounds (VOC). This ageing is often the cause of poor adhesion properties (Outhayon 2008).

Wettability, which reflects the ability of liquid coating products to spread over a surface, is the most often used property to characterise surface reactivity (De Moura 2006). Many significant correlations have been found between surface roughness criteria, wettability criteria (contact angle and surface energy), adhesion and coating lifetime (De Moura 2006; Khazaeian 2006; Outhayon 2008). Surfaces mainly constituted by peaks showed a relatively low wettability (Hernandez and Cool 2008) and did not allow for good coating anchoring.

Wettability is strongly influenced by many parameters: wood anatomy, ambient air nature, temperature and machining processes. Thus, sanding (Aydin 2004) as well as the increase of cutting speed in routing (Outhayon 2008) improves surface wettability. However, there is a faster decline of surface wettability with ageing for sanded than for routed surfaces, probably due to a higher capacity to exchange with exterior air. These results suggest that the wood samples can be stored without much modification to their surface properties if they are kept in an inert dry atmosphere at a rather low temperature and protected from ultraviolet rays in order to prevent surface oxidation and extractive migration. It is generally recommended that the surface coating be applied as soon as possible after machining and preferably within a week, especially for sanded pieces.

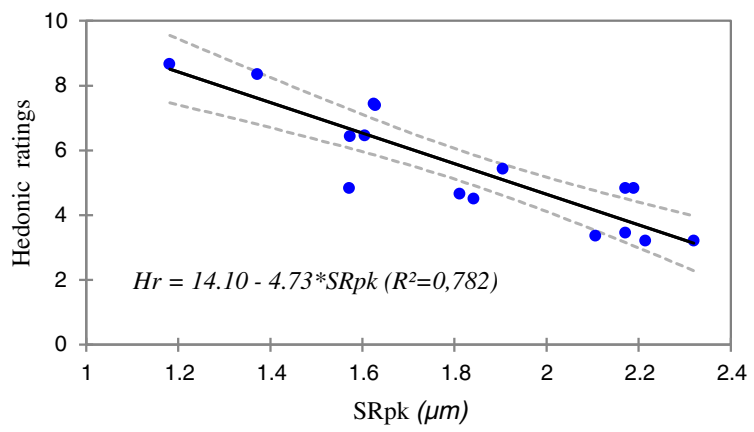

study on the routing of Famelona (from Ramananantoandro et al. 2013). The dashed lines correspond to the range of $95 \%$ confidence

Although all authors claim that the higher the roughness, the greater the wettability, there is more controversy concerning adhesion of glue-lines or the lifetime of coatings. In peripheral plaining of black spruce wood, an increase of the polar component of surface energy with the increasing of roughness has been observed. The existence of hydroxyl groups on the surface fosters liaison with the coating and leads to better adhesion (Cool and Hernández 2012). On the contrary, after sanding and milling of European spruce boards, there was no causal relationship between roughness, wettability and adhesion (Arnold 2010).

Two other criteria, complementary to the physicalchemical properties of surfaces, are often used to explain differences in adhesion and durability: cellular damage and fibrillation. The latter is defined as the total or partial detachment of microfibrils or fibril groups from the cell wall. Superficial cell fragments are torn and raised, leaving longitudinal grooves and a fluffy texture to the wood surface (Cool 2011). This phenomenon is strongly affected by wood anatomy and the cutting process. In the case of oak sanding, it has been shown that the orientation of the wood structure relative to the sanding band has as much importance as grain size, pressure or sanding speed (Marra and Syracuse 1943). Temperature also plays a role by increasing the pressure on a band without any abrasive in order to change the contact temperature, equivalent levels of fibrillation as those obtained with abrasive were observed (Marra and Syracuse 1943).

The raised grain phenomenon very often occurs during varnishing, and specifically while coating with aqueous finishing product. This gives a bad appearance to the coating film compared with a solvent-based varnish (Landry et al. 2013). Several studies have highlighted the relationship between fibrillation and some surface roughness parameters, describing the importance of the peaks on the surface and the depth roughness (Cool and Hernández 2011; Landry et al. 2013). The existence of fibrillation improves the adhesion of coatings through the increasing of surface roughness and of the area available for mechanical anchoring. However, the bundles of microfibrils must be strongly linked to the surface 
otherwise adhesion will be reduced. The difficulty is the lack of practical methods for the quantitative assessment of fibrillation.

Cell damage, which occurs through cell bending, crushing or tearing, has often been used to explain differences in behaviour between sanded and planed samples. These damages or cracks can be more or less deep or superficial. Therefore, the lumens of some cells are clogged with fragments torn from the neighbouring areas (Hernandez and Cool 2008). This damage, mainly linked to wood anatomy and machining processes, are usually well correlated with surface roughness criteria (Svk), which is often cited as a characteristic parameter for wood anatomy (Khazaeian 2006). Several studies on different machining processes have shown that sanded surfaces present more cell damage and are generally rougher (with better wettability) than planed surfaces (with sharp tools), without having a better coating. Roughness is thus not necessarily a relevant criterion, when used alone, to identify an ideal surface for optimal coating adhesion (Cool and Hernández 2011). Moreover, cellular damage has an impact on ageing of the coating, as damaged cells are more sensitive to failures due to swelling and shrinkage during wet and dry cycles. Micro-failures in the interface between the coating and the substrate significantly favour the loss of adhesion of the coating (Hernandez and Cool 2008). Finally, the entering of the liquid varnish depends on whether vessels are free, blocked by tylose or crushed (as in the case of sanded surfaces).

\subsection{The special case of veneers}

The veneer is the result of a primary conversion, but both faces of the veneer are strongly different. The upper face has the highest quality while the lower face (the open face) is more or less degraded by lathe checks. Moreover, veneer thickness uniformity is also important, whether for decorative uses or engineered wood products such as plywood or laminated veneer lumber. Thus, the quality of veneers is often the most important parameter in veneer cutting and should be keenly monitored (Denaud et al. 2012; Pot et al. 2014).

\section{Tool, machines and sensors}

\subsection{Automation and sensors}

The objective of wood machining is to answer several objectives: productivity, product quality, recovery, reactivity to the market and better working conditions, while taking into account cost, raw material, variety of customer needs, environment and social constraints. The manufacturing process is increasingly being controlled and automated by the use of specific equipment, software and databases (Iskra and Hernandez 2010; Mc Millin et al. 1984).

For different operations (bucking, log sawing, edging and cross cutting), the same list of operations has to be made: shape measurement, defect identification and non-destructive estimation of wood properties, cutting optimisation taking into account the production requirements, log or board positioning, cutting, sorting and storing the end product (Martin 1992). Usually the saw miller interacts with the machine controlling system. The sensors are usually based on non-contact techniques such as laser beams crossed by logs or boards using dedicated software for product geometry measurement. Industrial vision systems has been developed for defect detection and timber qualification by using cameras with white light, infrared or laser techniques (Collet 2014).

\subsection{Tool technology}

The cutting tool can have one or many (three for a saw tooth) sharp edges, with the fibre severing edge being the first to act and needing to be very keen. Depending on cutting process (green or dry wood), timber quality (knotty or not) and species (siliceous or not), the sharp edge should be resistant to heating, corrosion, abrasion or shocks. Depending on the end use of cut pieces, the tool wedge angle must sometimes be rather small $\left(20^{\circ}\right.$ in veneer cutting), and thus be very sensitive to bending and shocks.

The most common tool material remains forged tempered steel, but there are a huge variety of blade steels with varying hardness (more resistant to wear), toughness (more resistant to shocks) and chemical composition (more resistant to heating or corrosion). It should be recognised that master smith artisan skills remain unsurpassed and as yet very little is known about them.

Very hard and heat-resistant materials such as carbides, ceramics or diamond are increasingly being used for secondary processing operations, but only with wedge angles above $40^{\circ}$ and mostly for homogeneous wood-based materials.

Aside from handmade steel tools which use all available skills in steel alloy composition, steel forging and tool tempering, different coating techniques were used to enhance the cutting lifetime of industrial high-speed steel commonly used in metal cutting or low alloy-resistant steel (Labidi et al. 2005). Stellite tipping is one of the oldest methods and is very efficient for sawing high-density siliceous tropical woods (Chardin 1962). Nitriding steel gives promising results (Beer 1998; Nouveau et al. 2011). Thin coating with a hard material $\left(\mathrm{Cr}_{\mathrm{x}} \mathrm{N}_{\mathrm{y}}\right.$ type) using physical vapour deposition also gives promising results (Nouveau 2001; Nouveau et al. 2001).

Grinding and honing of the tool is a frequent and delicate operation during the whole tool life, and final handmade honing remains the best final preparation before cutting. In fact, even after a very good classical grinding, the tool edge is 
rather rough (Meyer 2003) at its tip with very tiny cracks which lead to damage in the first cutting lengths. This sort of "running in" process can be done before real cutting with sand blasting, which is more or less similar to handmade honing done on tool blades. This proved to be efficient in reducing wear in veneer cutting, at the same time improving coating adhesion (Nouveau et al. 2009).

\section{Conclusion}

During the last 50 years, much has been done on each wood machining topic, both in academic and industrial work, often using innovations and methods that have come from the metal machining sector.

Concerning the basic interaction between wood and tool, the specific nature of wood due to (i) its very strong anisotropy and porosity and (ii) its sensitivity to moisture and temperature of its constitutive polymers have been clarified. Very innovative and performant experimental devices have been built in order to study the different types of cutting modes for many species, using all available techniques in the field of metal cutting, which has led to a large set of experimental data.

Models have been developed in order to analyse experimental results and to try to predict useful parameters for factories. A serious effort has been made to improve the "pertinent" knowledge in wood mechanics for machining to feed the models: loading in directions parallel or perpendicular to the grain, up to high strain levels and high strain rates, for different loading modes, and at varying temperatures and moisture contents of the wood specimen. However, we need to confess that we are far from the corresponding knowledge that exists for metals. In addition to the higher complexity linked to anisotropy, the reality is that we are very far behind the achievements of modelling in metal cutting.

The basic tool-material couple experimental approach, which is very efficient for defining good machining parameters for a new material, has been used for a very small number of species relative to the very high diversity of wood structures.

With respect to experiments in woodcutting, significant progress in wood mechanical behaviour knowledge (both in green and dry states) and models related to easy-to-get pertinent parameters for mechanical and machining properties for each species are needed.

For primary conversion, much has been done in improving machines through the introduction of sensors and automation at every step in the process. Today sawing or peeling lines are computer-controlled with a huge available quantity of data from the logs, boards or on-going processes. The challenge, as elsewhere, is to manage this "big data" situation, following a thread to better and better links between log description (by
3D tomography, in the future), including traceability from the forest, process decisions, final product properties, customer requests and cost and profitability, using traceability tools at each output step.

In secondary processing and generation of surfaces, the introduction of sensors and process automation for most of the machining, transfer and stocking operations, which has come from the machining of metals, is well under way. There is a strong need to develop specific tools for analysis and measurement of solid wood machined surfaces for their geometrical, physical and chemical description, as well as their "aspect" (grain, motifs and colours) linked to consumers' perception. The existing measuring devices are still too slow and expensive to hope to depart from the scope of research laboratories and the development of new techniques (stereovision, interference, etc.) seems essential. Research on optimised routes for surface finishing, taking into account environment, energy consumption and workers health (Rajemison 2013), is needed today. Connections between 3D numerical images of wood structure (computed microtomography) and the prediction of wooden surface aspect are the challenge for the future of high-value added uses.

The transfer from the metal industry of numericallycontrolled machine tools to 3D routers in furniture or joinery factories has proven to be efficient for the most homogeneous and isotropic products such as MDF or very dense homogeneous woods. However, there is still a real scientific and technical problem for solid wood, which explains why hardwoods are used less today in these industries. At this time, we are still nowhere near reaching the basic skill of craftsmen for this kind of machining operation. A real "revolution" is needed in order to take into account, at the very beginning and at each step, the fluctuating local anisotropy and wide changes of wood porosity. It will be necessary to go deep inside craft skills, both in terms of the series of actions and the use of specialised tools for different situations, in order to reproduce standard craft-quality products from hardwoods.

Looking at tool technology, efficient experimental devices are available, allowing a huge amount of data to be obtained, but there is still a rather big lack of theoretical models for tool wear associated with tool material, the tool grinding process, wood species and machining conditions. There is also a gap between craftsmen-made tools and industrial tools at each step of tool making: steel composition, forging and hardening routes, and grinding and honing operations. Real progress had been made by using high-speed steel, stellite-tipped ductile steel and inserts made of very hard materials. Metal surface treatments using hard coatings derived from the metal industry were not so efficient in many cases for solid wood, and a deeper scientific approach in tool metallurgy for woodcutting conditions is needed.

Associated to experiments in wood cutting, significant progress in wood mechanical behaviour knowledge (both in 
green and dry state) and models relating easy-to-get pertinent parameters for each species to mechanical and machining properties are needed.

For primary conversion, much has been done in improving machines by introduction of sensors and automation at every step in the process. Sawing or peeling lines, to day, are computer controlled with a huge available quantity of data from the logs, the boards or on-going process. The challenge, as elsewhere, is to manage this "big data" situation, following a thread to better and better links between log description (by $3 \mathrm{D}$ tomography, in the future) including traceability from the forest, process decisions, final product properties, customer requests, cost and profitability, using traceability tools at each output step.

In second processing and generation of surfaces, introduction of sensors and process automation for most of the machining, transfer and stocking operations, coming from machining of metals, is well under way. There is a strong need to develop specific tools for analysis and measurement of solid wood machined surfaces for their geometrical, physical and chemical description, as well as their "aspect" (grain, motifs and colours) linked to consumer's perception. The existing measuring devices are still too slow and expensive to hope departing from the scope of research laboratories and the development of new techniques (stereovision, interference ...) seems essential. Research on optimised routes for surface finishing taking into account environment, energy consumption and workers health (Rajemison 2013) is needed today. Connexions between 3D numerical images of wood structure (computed micro-tomography) and prediction of wooden surface aspect is a challenge for the future high value added uses.

The transfer from metal industry of numerically controlled machine tools to 3D routers in furniture or joinery factories proves to be efficient for the most homogeneous and isotropic products like fibre boards or very dense homogeneous woods. But there is still a real scientific and technical problem for solid wood, explaining the reason why hardwoods are less used today in these industries. Until know, we are still nowhere near reaching the basic skill of craftsmen for this kind of machining operation. A real "revolution" is needed in order to take into account, at the very beginning and at each step, the fluctuating local anisotropy and wide changes of wood porosity. It will be necessary to go deep inside craft skills both in the series of actions and the use of specialised tools for different situations, in order to reproduce standard craft quality products from hardwoods.

Looking at tool technology, efficient experimental devices are available, allowing to obtain a huge amount of data, but there is still a rather big lack of theoretical models for tool wear associated with tool material, tool grinding process, wood species and machining conditions. There is also a gap between craftsmen made tools and industrial ones at each step of tool making: steel composition, forging and hardening routes, grinding and honing operations. Real progress had been done by using high-speed steel, stellite-tipped ductile steel or inserts made of very hard materials. Metal surface treatments using hard coatings derived from metal industry were not so efficient in many cases for solid wood, and a deeper scientific approach in tool metallurgy for wood cutting conditions is needed.

\section{References}

AFNOR (1994) Norme Française NF E 66-520, Couple « Outil/Matière » : domaine de fonctionnement des outils coupants, vol 1 à 6 . AFNOR Editions, Paris

Alauddin M, Choudhury IA, Baradie EMA, Hashmi MSJ (1995) Plastics and their machining: a review. J Mater Process Technol 54:40-46

Alméras T, Fournier M (2009) Biomechanical design and long-term stability of trees: Morphological and wood traits involved in the balance between weight increase and the gravitropic reaction. $\mathrm{J}$ Theor Biol 256:370-381

Almeras T, Thibaut A, Gril J (2005) Effect of circumferential heterogeneity of maturation strain, modulus of elasticity and radial growth on the regulation of stem orientation in trees. Trees 19:457-467

Altaner CM, Tokareva EN, Wong JCT, Hapca AI, McLean P, Jarvis MC (2009) Measuring compression wood severity in spruce. Wood Sci Technol 43:279-290

Arnold M (2010) Planing and sanding of wood surfaces. Effects on surface properties and coating performance, Proceedings of 7 th International Wood Coating Congress, Amsterdam, Congress paper $\mathrm{n}^{\circ} 32,12 \mathrm{p}$

Artozoul J, Lescalier C, Bomont O, Dudzinski D (2014) Extended infrared thermography applied to orthogonal cutting: Mechanical and thermal aspects. Appl Therm Eng 64:441-452

ASTM D1666 (2011) Standard test methods for conducting machining tests of wood and wood-base materials. ASTM International, West Conshohocken

Atkins AG (2003) Modelling metal cutting using modern ductile fracture mechanics: Quantitative explanations for some longstanding problems. Int J Mech Sci 45:373-396

Atkins AG (2009) The science and engineering of cutting. Elsevier, Oxford

Aydin I (2004) Activation of wood surfaces for glue bonds by mechanical pre-treatment and its effects on some properties of veneer surfaces and plywood panels. Applied Surface Science 233. Appl Surf Sci 233:268-274

Back EL (1991) Oxidative activation of wood surfaces for glue bonding. For Prod J 41:30-36

Barbacci A, Constant T, Farré E, Harroué M, Nepveu G (2008) Shiny beech wood is confirmed as an indicator of tension wood. IAWA J 29:35-46

Bardet S, Beauchêne J, Thibaut B (2003) Influence of basic density and temperature on mechanical properties perpendicular to grain of ten wood tropical species. Ann For Sci 60:49-59

Berglund A, Johansson E, Skog J (2014) Value optimized log rotation for strength graded boards using computed tomography. Eur J Wood Prod 72:635-642

Boulloud JC (1972) Recherches sur le déroulage au centre technique forestier tropical. Bois et forêts des tropiques 142:35-51

Bowden FP, Tabor D (1968) The friction and lubrication of solids. Clarendon, Oxford 
Castéra P, Nepveu G, Mahé F, Valentin G (1994) A study on growth stresses, tension wood distribution and other related wood defects in poplar (Populus euramericana cv 1214): end splits, specific gravity and pulp yield. Ann Sci For 51:301-313

Chardin A (1954) Peut-on scier tous les bois avec la même denture? Bois et forêts des tropiques 33:41-50

Chardin A (1957) L'étude du sciage par photographie ultra-rapide. Bois et forêts des tropiques $51: 40-51$

Chardin A (1958) Utilisation du pendule dynamométrique dans les recherches sur le sciage des bois. Bois et forêts des tropiques 58: 49-61

Chardin A (1962) L'utilisation des lames de scie à dents stellitées. Bois et forêts des tropiques $85: 41-54$

Chardin A (1966) L'étude de l'usure des dents de scie. Chapitre I: nécessité d'une étude de l'usure et choix d'une méthode de travail. Bois et forêts des tropiques 110:57-66

Chardin A (1967a) L'étude de l'usure des dents de scie. Chapitre I: nécessité d'une étude de l'usure et choix d'une méthode de travail (suite). Bois et forêts des tropiques 114:65-75

Chardin A (1967b) L'étude de l'usure des dents de scie. Chapitre II: mise en œuvre de la méthode adoptée. Bois et forêts des tropiques 116: $15-30$

Chardin A (1968a) L'étude de l'usure des dents de scie. Chapitre II: mise en œuvre de la méthode adoptée (suite). Bois et forêts des tropiques 120:49-65

Chardin A (1968b) L'étude de l'usure des dents de scie. Chapitre III: mode de publication des résultats. Bois et forêts des tropiques 122: $41-58$

Chardin A (1971) Sawtooth performance: Variables affecting tool wear. Proc IWMS 3:1-14

Chardin A (1973) Laboratory studies of $t$ temperature distribution on the face of a sawtooth. Proc IWMS 4:46-57

Childs THC, MacKawa K, Obikawa T, Yamane Y (2000) Metal machining; theory and applications. Arnold, London

Clair B, Jaouen G, Beauchene J, Fournier M (2003) Mapping radial, tangential and longitudinal shrinkages and relation to tension wood in discs of the tropical tree Symphonia globulifera. Holzforschung 57:665-671

Collet R. (2014), Contribution à la valorisation dans la construction des essnces forestières locales : des procédés au matériau, mémoire d'Habilitation à Diriger des Recherche, Université de Limoges, 6 mai 2014

Constant T, Badia M, Mothe F (2003) Dimensional stability of douglas fir and mixed beech-poplar plywood: Experimental measurements and simulations. Wood Sci Technol 37:11-28

Cool J (2011) Optimisation de l'usinage de finition du bois d'épinette noire pour fins d'adhésion, Dissertation, University of Laval

Cool J, Hernández R (2011) Performance of three alternative surfacing processes on black spruce wood and their effects on water-based coating adhesion. Wood Fiber Sci 43:365-378

Cool J, Hernández R (2012) Effects of peripheral planing on surface characteristics and adhesion of a waterborne Acrylic coating to black spruce wood. For Prod Soc 62:124-133

Costes JP, Ko PL, Ji T, Decès-Petit C, Altintas Y (2004) Orthogonal cutting mechanics of maple: Modeling a solid wood-cutting process. J Wood Sci 50:28-34

Daoui A, Descamps C, Marchal R, Zerizer A (2011) Influence of veneer quality on beech LVL mechanical properties. Maderas Cien Tecnol 13:69-83

Darmawan W, Rahayu I, Nandika D, Marcal R (2012) The importance of extractives and abrasives in wood material on the wearing of cutting tools. Bioresources 7:4715-4729

De Moura LF, 2006, Etude de trois procédés de finition des surfaces du bois d'érable à sucre pour fins de vernissage, Dissertation, University Laval, Québec
Denaud LE, Bléron L, Ratle A, Marchal R (2005) Vibro-acoustic analysis of wood peeling process: Temporal and spectral analysis. Proc IWMS 17:55-65

Denaud LE, Bléron L, Ratle A, Marchal R (2007) On-line control of wood peeling process: Acoustical and vibratory measurements of lathe checks frequency. Ann For Sci 64:569-575

Denaud LE, Bleron L, Eyma F, Marchal R (2012) Wood peeling process monitoring: a comparison of signal processing methods to estimate veneer average lathe check frequency. Eur J Wood Wood Prod 70: 253-261

Dietz H, Plötz F (2005) A new sawing method for the lumber industry (active curve sawing with arcoline). Proc IWMS 17:384-390

Dobner JR, Nutto ML, Higa AR (2013) Recovery rate and quality of rotary peeled veneer from 30-year-old Pinus taeda L. logs. Ann For Sci 70:429-437. doi:10.1007/s13595-013-0274-Z

Dufour-Kowalski S, Courbaud B, Dreyfus P, Meredieu C, de Coligny F (2012) Capsis: an open software framework and community for forest growth modelling. Ann For Sci 69:221-233

Dupleix A, Ould Ahmedou SA, Bleron L, Rossi F, Hughes M (2012) Rational production of veneer by IR-heating of green wood during peeling: Modeling experiments. Holzforschung 67:53-58

Dupleix A, Denaud LE, Bleron L, Marchal R, Hughes M (2013) The effect of log heating temperature on the peeling process and veneer quality: Beech, birch, douglas-fir and spruce case studies. Eur J Wood Wood Prod 71:163-171

Ernst H, Merchant ME (1941) Chip formation, friction and high quality machined surfaces. Surface treatment of metals. Am Soc Met 29: 299-378

Eyma F, Méausoone PJ, Martin P (2001) Influence of the transitional zone of wood species on cutting forces in the router cutting process $\left(90^{\circ} / 0^{\circ}\right)$. Holz Roh Werkst 59:489-490

Eyma F, Méausoone PJ, Martin P (2004) Study of the properties of thirteen tropical wood species to improve the prediction of cutting forces in mode B. Ann For Sci 61:55-64

Ferrand JC (1982) Etude des contraintes de croissance. Deuxième partie : variabilité en forêt des des contraintes de croissance du hêtre (Fagus sylvatica L.). Ann Sci For 39:187-218

Fischer R, Gottlober C, Oertel M, Wagenfuhr A, Darmawan W (2011) Effects of wood cutting with extreme inclined edges. Proc IWMS 20:22-29

Fournier M, Bordonné P, Guitard D, Okuyama T (1990) Growth stress patterns in tree stems. Wood Sci Technol 24:131-142

Fournier M, Bailleres H, Chanson B (1994) Tree biomechanics: Growth, cumulative pre-stresses and re-orientations. Biomimetics 2:229-251

Franz NC (1958) Analysis of the wood cutting process. Dissertation, University Ann Arbor

Fujiwara Y, Fujii Y, Okumura S (2005) Relationship between roughness parameters based on material ratio curve and tactile roughness for sanded surfaces of two hardwoods. J Wood Sci 51:274-277

Gardiner B, Barnett J, Saranpää P, Gril J (eds) (2014) The biology of reaction wood. Springer, Berlin

Gauvent M, Méausoone P-J, Martin P, Rocca E (2005) Impact of abrasion and corrosion by solid wood in tool's wear. Proc IWMS 17:571-580

Gibson L, Ashby M (1999) Cellular solids. Structure and properties, 2nd edn. Cambridge University Press, Cambridge

Gindy NNZ (1978) Machining characteristics of polymers. Dissertation, University of Aston in Birmingham

Goli G, Fioravanti M, Sodini N, Jiangang Z, Uzielli L (2005) Wood processing: a contribute to the interpretation of surface origin according to grain orientation. Proc IWMS 17:44-54

Goli G, Fioravanti M, Marchal R, Uzielli L, Busoni S (2010) Up-milling and down-milling wood with different grain orientations - the cutting forces behaviour. Eur J Wood Wood Prod 68:385-395

Gril J, Berrada E, Thibaut B (1993) Recouvrance hygrothermique du bois vert. II. Variations dans le plan transverse chez le châtaignier et 
l'épicéa et modélisation de la fissuration à coeur provoquée par l'étuvage. Ann Sci For 50:487-508

Guitard D (1987) Mécanique du matériau bois et composites. Cépaduès éditions, Toulouse

Gurau L (2007) Quantitative evaluation of the sanding quality in furniture manufacturing, Edition: Univ. of Brasov, Transylvania, ISBN: 978973-598-126-6

Gurau L, Mansfield-Williams H, Irle M, Cionca M (2009) Form error removal of sanded wood surfaces. Eur J Wood Wood Prod 67:219 227

Hamilton MG, Blackburn DP, McGavin RL, Baillères H, Vega M, Potts BM (2014) Factors affecting log traits and green rotary-peeled veneer recovery from temperate eucalypt plantations. Ann For Sci. doi: 10.1007/s13595-014-0430-0

Hancock WV, Feihl O (1980) Lathe operator manual. Special publication SP 4 R., Forintek Canada Corporation

Hapca AI (2004) Distribution de bois de compression dans l'arbre en relation avec sa forme externe. Application à l'épicéa commun (Picea abies (L.) Karst.). Thèse ENGREF

Hardy BL, Moncel M-H (2011) Neanderthal use of fish, mammals, birds, starchy plants and wood $125-250,000$ years ago. PLoS ONE 6: e23768, doi:10.1371

Hernandez RE, Boulanger J (1997) Effect of the rotation speed on the size distribution of black spruce pulp chips produced by a chipper-canter. For Prod J 47:43-49

Hernandez RE, Cool J (2008) Evaluation of three surfacing methods on paper birch wood in relation to water and solvent borne coating performance. Wood Fiber Sci 40:459-469

Hoadley RB (1962) Dynamic equilibrium in veneer cutting. For Prod J 12:116-123

Horner Y (2005) Le biscuit dans la poche. Editions du rocher, Monaco

Hutton S, Chonan S, Lehmann B (1987) Dynamic response of a guided circular saw. J Sound Vib 112:527-539

Iskra P, Hernandez RE (2010) Towards a process monitoring and control of a CNC wood router: development of an adaptive control system for routing white birch. Wood Fiber Sci 42:523-535

ISO 25178-2 (2012) Geometrical product specifications (GPS) - surface texture: areal-part 2: terms, definitions and surface texture parameters. ISO, Geneva

Jeronimidis G (1980) The fracture energy of wood and the relations between toughness and morphology. Proc R Soc Lond B208:447460

Jouty R (1955) Le mécanisme de la coupe des métaux. Thèse d'état ès sciences, Paris

Jullien D, Laghdir A, Gril J (2003) Modelling log-end cracks due to growth stresses: calculation of the elastic energy release rate. Holzforschung 57:407-414

Jullien D, Widmann R, Loup C, Thibaut B (2013) Relationship between tree morphology and growth stress in mature European beech stands. Ann For Sci 70:133-142

Kimura S, Okai R, Yokochi H (1994) Dynamic characteristics of bansaws-Resonance and washbording in bandsaws. Mokuzai Gakkaishi 42:333-342

Kinoshita N (1983) Analysis of the veneer-formation process II (in Japanese). Mokuzai Gakkaishi 29:877-883

Kivimaa E (1950) Cutting force in wood working. Dissertation, Finland State Institute for Technical Research

Klamecki BE (1979) A review of wood cutting tool wear literature. Holz Roh Werkst 37:265-276

Kobayashi A (1967) Machining of Plastics. McGraw-Hill, New York

Koch P (1964) Wood machining process. Ronald press, Cambridge

Koch P (1985) Chapter 18: machining. Utilization of hardwoods growing on southern pines sites. Volume 2, USDA, Agriculture handbook $\mathrm{N}^{\circ}$ 605 , chap. 18 , pp 1687-2281

Kubler H (1987) Growth stresses and related wood properties. Forestry Abstr 48:130-189
Labidi C, Collet R, Nouveau C, Beer P, Nicosia S, Djouadi MA (2005) Surface treatments of tools used in industrial wood machining. Surf Coat Technol 200:118-122

Landry V, Blanchet P, Cormier LM (2013) Water-based and solventbased stains: Impact on the grain raising in Yellow Birch. Bioresources 8:1997-2009

Larricq P, Costes J-P, Le Breton P, Cassou G (2000) Quality surface characteristics in high speed machining, Proceedings of the 1 st International Symposium on Wood Machining, pp 203-209

Leban JM, Triboulot P (1994) Défauts de forme et états de surface. Le bois matériau d'ingénierie, éditeur ARBOLOR, pp 334-363

Lemaster RL, Dornfeld DA (1982) Measurement of surface quality of sawn and planed surfaces with a laser. Proc IWMS 7:54-62

Lemorini C, Plummer TW, Braun DR, Crittenden AN, Ditchfield PW, Bishop LC, Hertel F, Oliver JS, Marlowe FW, Schoeninger MJ, Potts R (2014) Old stones' song: Use-wear experiments and analysis of the Oldowan quartz and quartzite assemblage from Kanjera South (Kenya). J Hum Evol 72:10-25

Leney L (1960) A photographic study of veneer formation. For Prod J 10: 133-139

Longuetaud F, Mothe F, Leban JM (2007) Automatic detection of the heartwood/sapwood boundary within Norway Spruce (Picea abies (L.) Karst.) logs by means of CT images. Comput Electron Agric 58: $100-111$

Longuetaud F, Mothe F, Kerautret B, Krähenbühl A, Hory L, Leban J-M, Debled-Rennesson I (2012) Automatic knot detection and measurements from X-ray CT images of wood: a review and validation of an improved algorithm on softwood samples. Comput Electron Agric 2012:77-89

Lundberg AS, Axelsson BOM (1993) Studies of the cutting forces and the chip formation process when cutting frozen wood. Proc IWMS 11:57-72

Luo J, Arnold R, Ren S, Jiang Y, Lu W, Peng Y, Xie Y (2013) Veneer grades, recoveries, and values from 5-year-old eucalypt clones. Ann For Sci 70:417-428. doi:10.1007/s13595-013-0268-x

Lusth H, Gradin P, Hellström L (2013) A theoretical model for the prediction of energy consumption during the chipper canter process. Nord Pulp Pap Res J 28:211-215

Lutz JF (1974) Techniques for peeling, slicing and drying veneer. Forest products laboratory, Madison Report $\mathrm{N}^{\circ} 228$

Lutz JF (1977) Wood veneer: log selection, cutting and drying. U.S. Dep. Agric., Technical bulletin $\mathrm{N}^{\circ} 1577$

Mallock A (1881) The action of cutting tools. Proc R Soc 33:127-139

Marchal R, Mothe F (1994) Appréciation du bois de chêne (Quercus robur L, Quercus petraea Liebl) par les consommateurs et les professionnels français du bois. Ann For Sci 51:213-231

Marchal R, Jullien D, Mothe F, Thibaut B (1993) Mechanical aspects of heating wood in rotary veneer cutting. Proc IWMS 11:257-278

Marchal R, Gaudillière C, Collet R. (2004) Technical feasibility of an embedded wood heating device on the slicer or the peeling lathe. Proceedings of 1 st International Symposium Veneer Processing and Products Proceedings, Cluny, pp 29-44

Marchal R, Mothe F, Denaud L-E, Thibaut B, Bléron L (2009) Cutting forces in wood machining-Basics and applications in industrial processes. A review. Holzforschung 63:157-167

Marra GG, Syracuse I (1943) An analysis of the factors responsible for raised grain on the wood of oak following sanding and staining. Trans ASME 65:177-185

Martin P (1992) Bois et Productique. Cépaduès éditions, Toulouse

Mc Millin CW, Conners RW, Huber HA (1984) ALPS: a potential new automated lumber processing system. For Prod J 34:13-20

McKenzie WM (1961) Fundamental analysis of the wood cutting process. Dissertation, University of Michigan

Méausoone P-J, Aguilera A, Martin P (2001) Choice of optimal conditions in wood machining using the "coupled tool-material" method. Proc IWMS 15:37-47 
Merhar M, Bučar B (2012) Cutting force variability as a consequence of exchangeable cleavage fracture and compressive breakdown of wood tissue. Wood Sci Technol 46:965-977. doi:10.1007/s00226011-0457-4

Meyer B (2003) L'affûtage et l'entretien de vos outils à bois, main et machine-Tome 1. Editions de la canopée, Gorniès

Mote CD, Szymani R (1977) Principal developments in thin circular saw vibration and control research. Part 1. Holz Roh Werkst 35:189-196

Mothe F (1985) Essai et comparaison de trois méthodes de classement de surface de bois massif pour leur rugosité : méthodes pneumatique et sensorielles. Ann Sci For 42:435-452

Mothe F, Thibaut B, Marchal R, Negri M (1997) Rotary cutting simulation of heterogeneous wood: application to douglas fir peeling. Proc IWMS 13:411-428

Mothe F, Constant T, Leban JM (2002) Simulating veneering and plywood manufacturing of virtual trees described by a growth and wood quality simulation software. Proceedings of 4th workshop IUFRO S5.01.04, Harrison hot springs, pp 519-527

Murase Y (1979) Effect of temperature on friction between wood and steel (in Japanese with English summary). Mokuzai Gakkaishi 25: 264-271

Nagatomi K, Yoshida K, Banshoya K, Murase Y (1993) Recognition of wood cutting conditions trough cutting sounds I: effect of tool system's stiffness and tool wear on the generation of sound in cutting parallel to the grain. Mokuzai Gakkaishi 39:521-528

Naylor A, Hackney P (2013) A review of wood machining literature with a special focus on sawing. Bioresources 8:3122-3135

NF EN ISO 4287 (1998) Spécification géométrique des produits (GPS) État de surface : méthode du profil-Termes, définitions et paramètres d'état de surface. ISO, Genève

Noël M, Bocquet A (1987) Les homes et le bois. Histoire et technologie du bois de la préhistoire à nos jours. Hachette, Paris

Nouveau C, Djouadi MA, Decès-Petit C, Beer P, Lambertin M (2001) Influence of CrxNy coatings deposited by magnetron sputtering on tool service life in wood processing. Surf Coat Technol 142-144: 94-101

Nouveau C, Labidi C, Collet R, Benlatreche Y, Djouadi MA (2009) Effect of surface finishing such as sand-blasting and CrAlN hard coatings on the cutting edge's peeling tools' wear resistance. Wear 267:1062-1067

Nouveau C, Steyer P, Mohan Rao KR, Lagadrillere D (2011) Plasma nitriding of $90 \mathrm{CrMoV} 8$ tool steel for the enhancement of hardness and corrosion resistance. Surf Coat Technol 205:4514-4520

Ohtani T (2007) Mechanical analysis of cellular deformation and fracture in wood cutting process. Proc IWMS 18:215-221

Orlowski K, Sandak J, Tanaka C (2007) The critical rotational speed of circular saw: simple measurement method and its practical implementations. J Wood Sci 53:388-393

Ormarsson S, Dahlblom O, Johansson M (2009) Finite element study of growth stress formation in wood and related distortion of sawn timber. Wood Sci Technol 43:387-403

Pałubicki B, Marchal R, Butaud JC, Denaud LE, Bléron L, Collet R, Kowaluk G (2010) A method of lathe checks measurement: SMOF device and its software. Eur J Wood Wood Prod 68:151-159

Pfeiffer R, Collet R, Denaud L, Fromentin G (2014) Analysis of chip formation mechanisms and modelling of slabber process. Wood Sci Technol. doi:10.1007/s00226-014-0680-x

Polge H (1981) Influence des éclaircies sur les contraintes de croissance du hêtre. Ann Sci For 38:407-423

Pomey J (1970) Etat actuel des connaissances fondamentales sur la coupe des métaux. Bulletin du cercle d'étude des métaux, $\mathrm{N}^{\circ}$ spécial 10.70

Porankiewicz B, Iskra P, Jozwiak K, Tanaka C, Zborowski W (2008) High speed steel tool wear after wood milling in the presence of high temperature tribochemical reactions. Bioresources 3:838-858

Pot G, Denaud L, Collet R (2014) Numerical study of the influence of veneer lathe checks on the elastic mechanical properties of laminated veneer lumber (LVL) made of beech. Holzforschung. doi:10.1515/hf-2014-0011

Radi M, Castera P (1992) Qualification de la forme de deux pins maritimes en liaison avec la structure de leur bois. Ann Sci For 49:185200

Rahayu I, Denaud L, Marchal R, Darmawan W (2014) Ten new poplar cultivars provide laminated veneer lumber for structural application. Ann For Sci. doi:10.1007/s13595-014-0422-0

Ramananantoandro T, Larricq P, Eterradossi O (2005) Relationship between $3 \mathrm{D}$ roughness parameters and tactile perception of surface roughness on maritime pine wood and MDF. Proc IWMS 17:298307

Ramananantoandro T, Ramanakoto MF, Rajemison AH, Eyma F (2013) Relationship between density and aesthetic attributes of wood and preference of Malagasy consumers. Ann For Sci 70:649-658

Richards J (1872) A treatise on the construction and operation of woodworking machines. E \& NF Spon, London

Riesco-Muñoz G, Remacha Gete A, Gasalla Regueiro M (2013) Variation in log quality and prediction of sawing yield in oak wood (Quercus robur). Ann For Sci 70:695-706. doi:10.1007/s13595013-0314-8

Roblot G, Coudegnat D, Bléron L, Collet R (2008) Evaluation of the visual stress grading standard on French Spruce (Picea excelsa) and Douglas-fir (Pseudotsuga menziesii) sawn timber. Ann For Sci 65:812-815

Roussel JR, Mothe F, Krähenbühl A, Kerautret B, Debled-Rennesson I, Longuetaud F (2014) Automatic knot segmentation in CT images of wet softwood logs using a tangential approach. Comput Electron Agric 104:46-56

Sales C (1990) La scie à ruban - théorie et pratique du sciage des bois en grumes. CTFT, Nogent sur Marne

Sandak J, Negri M (2005) Wood surface roughness - what is it? Proc IWMS 17:242-250

Sandak J, Negri M, Tanaka C (2004) Sensors for evaluation of wood surface smoothness. Proceedings of the 2nd International Symposium on Wood Machining, pp 343-350

Saurat J, Guéneau P (1976) Growth stress in beech. Wood Sci Technol 10:111-123

Schajer GS (1985) Why are guided circulars saws more stable than unguided saws? Proc IWMS 8:135-147

Schajer GS (1986) Simple formulas for natural frequencies and critical speeds of circular saws. For Prod J 36:37-43

Scholz F, Riegel A, Ratnasingam J (2007) Quality and assessment of sanded surfaces. Proc IWMS 18:297-310

Sernek M, Kamke FA, Glasser WG (2004) Comparative analysis of inactivated wood surfaces. Holzforschung 58:22-31

Simonin G, Méausoone P-J, Rougié A, Triboulot P (2009) Carbide characterization for Spruce rip-sawing. Pro Ligno 5:49-58

Sinn G, Sandak J, Ramananantoandro T (2009) Properties of wood surfaces-Characterisation and measurement, A review. Holzforschung 63:196-203

Stewart HA (1971) Chip formation when orthogonally cutting wood against the grain. J Wood Sci 3:193-203

Stewart HA (1977) Optimum rake angle related to selected strength properties of wood. For Prod J 27:51-53

Sugiyama S (1971a) On behaviour of deflexion caused in wood by pressure bar compression. Mokuzai Gakkaishi 17:96-102

Sugiyama S (1971b) An analysis on development of dynamic equilibrium condition in veneer cutting. Mokuzai Gakkaishi 17:103-110

Tanaka C, Shiota Y, Takahashi A, Nakamura M (1981) Experimental studies on band saw blades vibration. Wood Sci Technol 15:145159

Thibaut B. (1988) Le processus de coupe du bois par déroulage. Thèse d'état, Montpellier 
Thibaut B (2004) Peeling small diameter logs. Proceedings of 1st International Symposium "Veneer processing and products », Cluny, pp 97-108

Thibaut B, Beauchêne J (2004) Links between wood machining phenomena and wood mechanical properties: the case of $0^{\circ} / 90^{\circ}$ orthogonal cutting of green wood. Proceedings of the 2nd Int. Symposium on Wood Machining, Vienna, pp 149-160

Thomas R, (2000) Analyse des formes de troncs par photogrammétrie pour caractériser la qualité des bois. Application au Pin Sylvestre de Lozère. Thèse ENGREF, Montpellier

Trent EM (2004) Metal cutting, 4th edn. Butterworth-Heinemann, Boston

Triboulot P (1981) Application de la mécanique de la rupture aux bois massifs considérés comme matériaux de construction. Thèse de l'Université de Technologie de Compiègne

Triboulot P (1984) Réflexions sur les surfaces et mesures des états de surface du bois. Ann Sci For 41:35-354

Triboulot P, Kremer P, Martin P, Leban JM (1991) Planing of Norway spruce with very varied ring width. Holz Roh Werkst 49:184

Watanabe K, Yamashita K, Noshiro S (2012) Non-destructive evaluation of surface longitudinal growth strain on Sugi (Cryptomeria japonica) green logs using near-infrared spectroscopy. J Wood Sci 58:267272

Woodson GE, Koch P (1970) Tool forces and chip formation in orthogonal cutting of loblolly pine. Department of Agriculture-Forest Service, research paper SO-52

Yang JL, Baillères H, Okuyama T, Muneri A, Downes G (2005) Measurement methods for longitudinal surface strain in trees: a review. Aust For 68:34-43

Zhao C, Tanaka C, Nakao T, Takahashi A (1991) Relationships between surface-finish qualities and acoustic emission count rates in circuler sawing II. Mokuzai Gakkaishi 37:434-440

Zorev NN (1966) Metal cutting mechanics. Pergamon Press, Oxford

\section{PhD Thesis defended in France during the last 30 years in the field of wood machining}

Abdallah R (2011) Détermination des facteurs influençant la coupe et la qualité des plaquettes issues du déchiquetage du bois par des machines forestières. Thèse de l'Université Henri Poincaré Nancy 1

Aguilera AAL (2000) Optimisation des conditions de coupe pour l'usinage du bois - application de la méthodologie du Couple Outil Matière au défonçage des panneaux de fibres de densité moyenne. Thèse de l'université Henri Poincaré, Nancy I

Aubert M (1987) Recherche de relations entre caractéristiques simples du bois de chêne rouge (Quercus rubra L.) mesurées par voie non destructive et deux de ses propriétés technologiques : stabilité dimensionnelle des planches et qualité des placages d'ébénisterie. Thèse de l'Université Henri Poincaré Nancy 1

Beauchêne J (1996) Evolution du comportement mécanique du bois vert avec la température - application à l'étude du déroulage et du tranchage de quelques bois Guyanais. Thèse ENGREF, Kourou

Beer P (1998) Etude de l'influence des modifications de la surface de l'outil sur la qualité de la coupe par déroulage. Thèse ENSAM Cluny et Université de Varsovie, Varsovie

Bonduelle A (1994) Caractérisation du panneau de particules surfacé mélaminé par son aptitude à l'usinabilité. Thèse de l'Université Henri Poincaré Nancy 1

Bonin V (2006) Modélisation analytique de la formation du copeau durant le procédé de déroulage du bois de hêtre. Thèse ENSAM Cluny

Boucher J (2007) Caractérisation de l'usinage en coupe rotative; interaction outil - matière - machine - processus. Thèse de l'Université Henri Poincaré Nancy 1
Boury S (1998) Relation entre la qualité des placages constitutifs et les caractéristiques d'un LVL de chêne (Quercus petreae Liebl. et Quercus robur L.p.p. : Usinabilité et durabilité. Thèse ENSAM, Cluny

Chabrier P. (1997) Amélioration de la qualité et du rendement matière des sciages : cas des scies circulaires. Thèse de l'Université Henri Poincaré Nancy 1

Coelho C (2006) Influence de l'usinage du bois sur les caractéristiques objectives et sur la perception subjective de l'aspect d'une finition. Thèse de l'Université Henri Poincaré Nancy $1 \&$ de l'Université de Porto

Collet R (1984) Détection des singularités du bois. Exploration interne du matériau par micro-ondes. Thèse de l'Université Henri Poincaré Nancy 1

Costes JF (2001) Approche de l'usinage à grande vitesse du bois : application au défonçage. Thèse de l'université Paul Sabatier Toulouse III

Decès-Petit D (1996) Etude des phases transitoires au cours du déroulage de bois. Thèse ENSAM, Cluny

Denaud L (2006) Analyses vibratoires et acoustiques du déroulage. Thèse ENSAM, Cluny

Dupleix A (2013) Feasability of wood peeling assisted by infrared. Thèse ENSAM-ParisTech \& Aalto University (Finland)

Eyma F (2002) Influence des caractéristiques physico-mécaniques du bois massif sur l'usinage. Interactions avec la méthodologie du Couple-Outil-Matière. Thèse de l'Université Henri Poincaré Nancy 1

Gauvent M (2006) Optimisation de la durée de vie d'un outil de coupe pour l'industrie du bois. Analyse et compréhension des modes d'usure. Mise au point de solutions innovantes avec tests industriels. Thèse de l'Université Henri Poincaré Nancy 1

Goli G (2003) Surfaces de bois obtenues par défonçage : étude de la mécanique de formation et des défauts induits. Thèse de l'Université de Florence \& de l'ENSAM Cluny

Jouffroy D (1999) Vers une démarche d'intégration de la sécurité à la conception des machines à bois semi-automatisées. Thèse de l'Université Henri Poincaré Nancy 1

Khazaeian A (2006) Caractérisation 3D de l'état de surface du bois : stratégie de mesure - influence des paramètres liés à l'essence et à l'usinage. Thèse de l'Université Paul Sabatier, Toulouse III

Levaillant G (1978) Détermination de conditions de coupe performantes pour l'usinage de pièces unitaires et de petites séries. Thèse de l'Université Henri Poincaré Nancy 1

Marchal R (1989) Valorisation par tranchage et déroulage des bois de chênes méditerranéens (Quercus ilex, Quercus pubescens, Quercus suber). Thèse de l'Université Henri Poincaré Nancy 1

Martin P (1997) L'entité d'usinage au service de l'ingénierie concourante : application à la gamme automatique dans l'ameublement. Thèse de l'Université Henri Poincaré Nancy 1

Méausoone PJ (1996) Approche en ingénierie concourante pour les industries du Bois. Thèse de l'Université Henri Poincaré Nancy 1

Mothe F (1988) Aptitude au déroulage du bois de douglas. Conséquences de l'hétérogénéité du bois sur la qualité des placages. Thèse de l’Université Henri Poincaré Nancy 1

Movassaghi E (1985) Influence des paramètres micro-densitométriques du bois, sur les efforts de coupe et la qualité des placages de Douglas et de Châtaignier obtenus par déroulage. Thèse de l'Université Henri Poincaré Nancy 1

Nouveau C (2001) Etude de revêtements durs $\left(\mathrm{Cr}_{\mathrm{x}} \mathrm{N}_{\mathrm{y}}\right)$ obtenus par méthodes PVD. Réalisation et caractérisation. Application à l'usinage du bois. Thèse ENSAM Cluny 
Outhayon A (2008) Influence de paramètres d'usinage et de stockage sur les propriétés fonctionnelles des surfaces de bois de Douglas. Thèse ENSAM Cluny

Rajemison AH (2013) Proposition d'essences de substitution aux bois précieux en épuisement par la connaissance des propriétés du matériau bois: Cas du Palissandre de Madagascar - Application en ameublement. Thèse Université Paul Sabatier Toulouse III et Université. d'Antananarivo

Ramananantoandro T (2005) Implications tactiles et visuelles de la rugosité du bois et des matériaux dérivés du bois de Pin maritime. Thèse de l'Ecole Nationale Supérieure des Mines de Saint Etienne
Rivat JM (1996) Amélioration des performances des scies à ruban. Thèse de l'Université Henri Poincaré Nancy 1

Rougié A (2009) Analyse et conception d'un outil de coupe pour la valorisation des sous-produits d'élagage des haies. Démarche intégrée d'innovation et de prototypage. Thèse de l'Université Henri Poincaré Nancy 1

Simonin G (2010) Amélioration de la performance des outils pour la première transformation du bois - Thèse de l'Université Henri Poincaré Nancy 1

Zerizer A (1991) Contribution à l'étude de l'usinabilité du M.D.F. Thèse de l’Université Henri Poincaré Nancy 1 